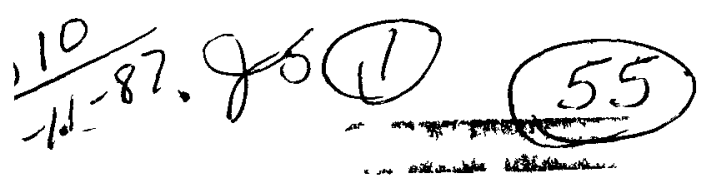

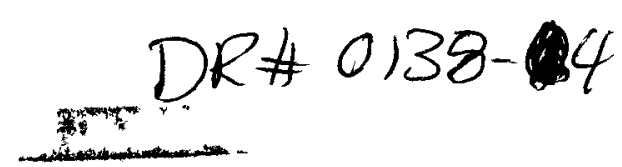

BMI/ONWI-627

\title{
Influence of Variables on the Consolidation and Unconfined Compressive Strength of Crushed Salt
}

\author{
Technical Report
}

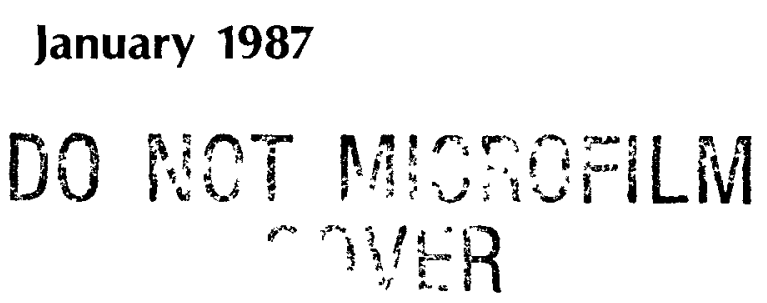

Tom W. Pfeifle

Paul E. Senseny

Kirby D. Mellegard

of

RE/SPEC Inc.

prepared for

Office of Nuclear Waste Isolation

Battelle Memorial Institute

505 King Avenue

Columbus, OH 43201-2693

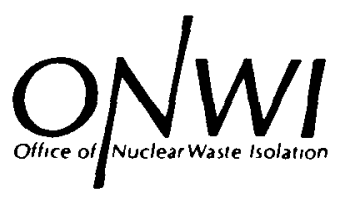

BATTELLE Project Management Division - 


\section{DISCLAIMER}

This report was prepared as an account of work sponsored by an agency of the United States Government. Neither the United States Government nor any agency Thereof, nor any of their employees, makes any warranty, express or implied, or assumes any legal liability or responsibility for the accuracy, completeness, or usefulness of any information, apparatus, product, or process disclosed, or represents that its use would not infringe privately owned rights. Reference herein to any specific commercial product, process, or service by trade name, trademark, manufacturer, or otherwise does not necessarily constitute or imply its endorsement, recommendation, or favoring by the United States Government or any agency thereof. The views and opinions of authors expressed herein do not necessarily state or reflect those of the United States Government or any agency thereof. 


\section{DISCLAIMER}

Portions of this document may be illegible in electronic image products. Images are produced from the best available original document. 


\section{1 \\ $\because$ \\ BIBLIOGRAPHIC DATA}

Pfeifle, Tom W., Paul E. Senseny, and Kirby D. Mellegard, 1987. Influence of Variables on the Consolidation and Unconfined Compressive Strength of Crushed Salt, BMI/ONWI-627, prepared by RE/SPEC Inc. for the Office of Nuclear Waste Isolation, Battelle Memorial Institute, Columbus, $\mathrm{OH}$.

\section{NOTICE}

This report was prepared as an account of work sponsored by an agency of the United States Government. Neither the United States Government nor any agency thereof, nor any of their employees, makes any warranty, expressed or implied, or assumes any legal liability or responsibility for the accuracy, completeness, or usefulness of any information, apparatus, product, or process disclosed, or represents that its use would not infringe privately owned rights. Reference herein to any specific commercial product, process, or service by trade name, trademark, manufacturer, or otherwise, does not necessarily constitute or imply its endorsement, recommendation, or favoring by the United States Government or any agency thereof. The views and opinions of authors expressed herein do not necessarily state or reflect those of the United States Government or any agency thereof.

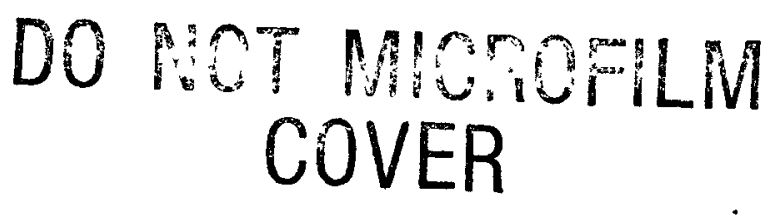

Printed in the United States of America Available from

National Technical Information Service

U.S. Department of Commerce

5285 Port Royal Road

Springfield, VA 22161

NTIS price codes

Printed copy: A05

Microfiche copy: A01 


\section{BMI/ONWI-627 \\ Distribution Category UC-70}

BMI/ONWI--627

DE87 005209

\section{Influence of Variables on the Consolidation and Unconfined Compressive Strength of Crushed Salt}

Technical Report

January 1987

Tom W. Pfeifle

Paul E. Senseny

Kirby D. Mellegard

of

RE/SPEC Inc.

prepared for

Office of Nuclear Waste Isolation

Battelle Memorial Institute

505 King Avenue

Columbus, OH 43201-2693

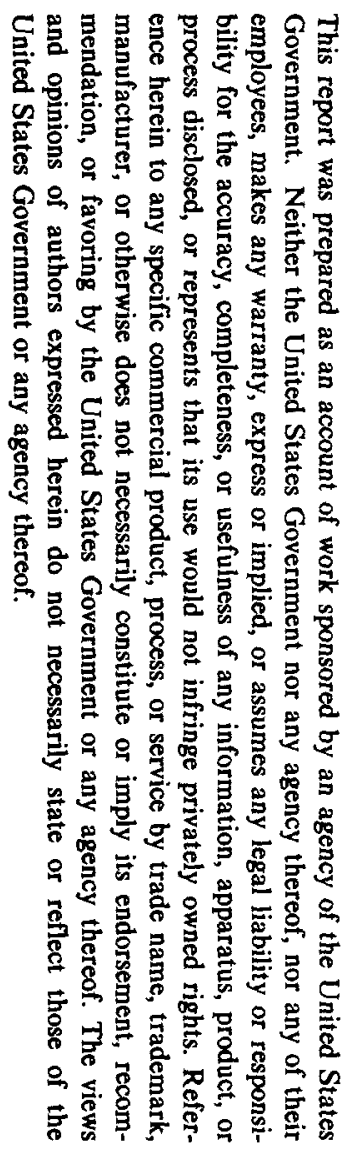

8
8
8
2

The content of this report was effective as of August 1984. This report was prepared by RESSPEC Inc., Rapid DE-AC02-83CH10140 with the U.S. Department of Energy. 


\section{ABSTRACT}

Eight hydrostatic compression creep tests were performed on crushed salt specimens fabricated from Avery Island dome salt. Following the creep test, each specimen was tested in unconfined compression. The experiments were performed to assess the influence of the following four variables on the consolidation and unconfined strength of crushed salt: grain size distribution, temperature, time, and moisture content. The experiment design comprised a half-fraction factorial matrix at two levels. The levels of each variable investigated were grain size distribution, uniform-graded and well-graded (coefficient of uniformity of 1 and 8 ); temperature $25^{\circ} \mathrm{C}$ and $100^{\circ} \mathrm{C}$; time, $3.5 \mathrm{x}$ $10^{3} \mathrm{~s}$ and $950 \times 10^{3} \mathrm{~s}$ (approximately 60 minutes and 11 days, respectively); and moisture content, dry and wet ( 85 percent relative humidity for 24 hours). The hydrostatic creep stress was $10 \mathrm{MPa}$. The unconfined compression tests were performed at an axial strain rate of $1 \times 10-5 s-1$. Results show that the variables time and moisture content have the greatest influence on creep consolidation, while grain size distribution and, to a somewhat lesser degree, temperature have the greatest influence on total consolidation. Time and moisture content and the confounded two-factor interactions between either grain size distribution and time or temperature and moisture content have the greatest influence on unconfined strength. 
FOREWORD

The National Waste Terminal Storage program was established in 1976 by the U.S. Department of Energy's predecessor, the Energy Research and Development Administration. In September 1983, this program became the Civilian Radioactive Waste Management (CRWM) Program. Its purpose is to develop technology and provide facilities for safe, environmentally acceptable, permanent disposal of high-level waste (HLW). HLW includes wastes from both commercial and defense sources, such as spent (used) fuel from nuclear power reactors, accumulations of wastes from production of nuclear weapons, and solidified wastes from fuel reprocessing.

The information in this report pertains to the rock mechanics studies of the Salt Repository Project of the Office of Geologic Repositories in the CRWM Program. 
TABLE OF CONTENTS

Page

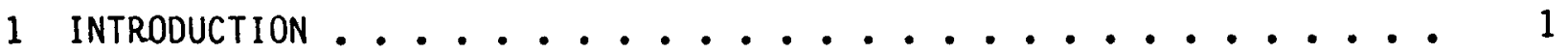

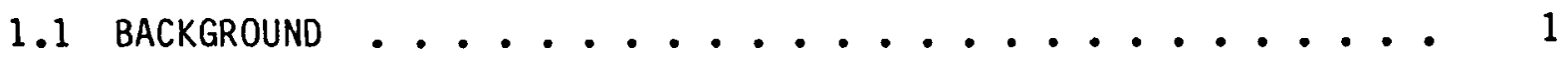

1.2 APPROACH AND SCOPE $\ldots \ldots \ldots 2$

1.3 REPORT ORGANIZATION ............... 5

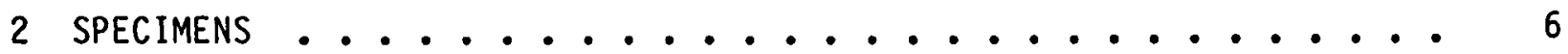

2.1 SALT CRUSHING AND SIZING ................... 6

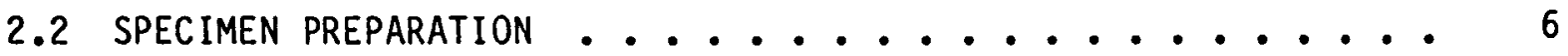

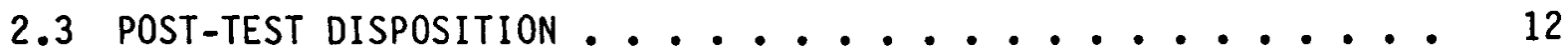

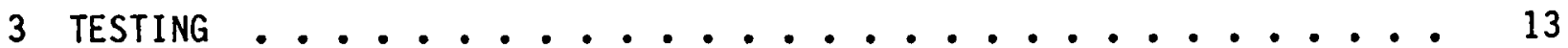

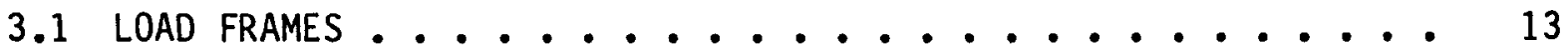

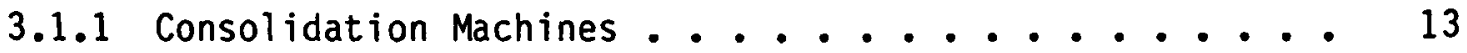

3.1 .2 MTS Universal Load Frame ............ 15

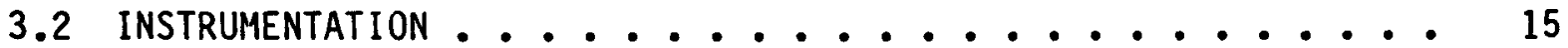

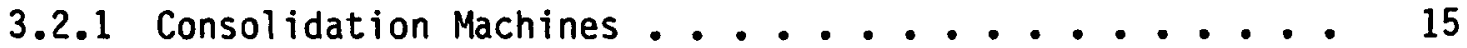

3.2 .2 MTS Universal Load Frame ............ 17

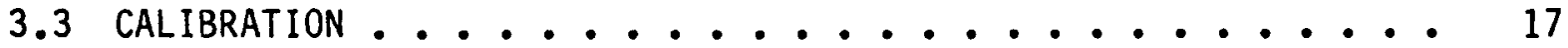

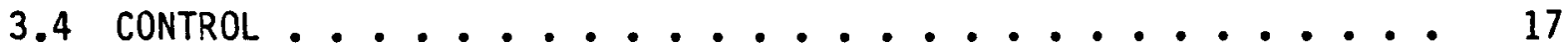

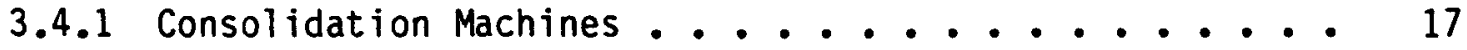

3.4.2 MTS Universal Load Frame ............ 17

3.5 TEST PROCEDURES ........................... 19

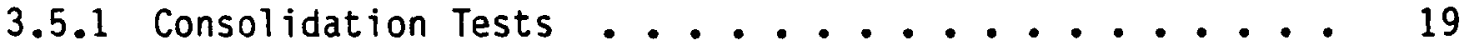

3.5.2 Unconfined Compression Tests .......... 19

4 RESULTS ................................ 21

4.1 CONSOLIDATION TESTS ............................. 21

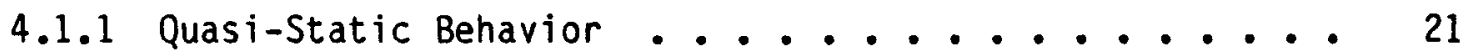

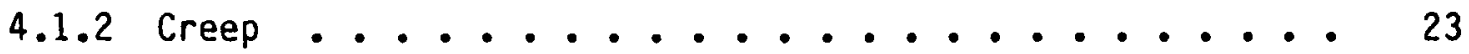

4.2 UNCONFINED COMPRESSION TESTS $\ldots \ldots 27$ 


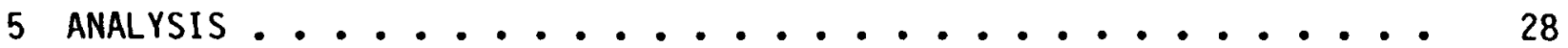

5.1 DISCUSSION ........................... 28

5.2 BULK DENSITY RATIO FOR CREEP CONSOLIDATION $\ldots \ldots . \ldots . \ldots 32$

5.3 BULK DENSITY RATIO FOR TOTAL CONSOLIDATION ........ 32

5.4 UNCONFINED COMPRESSIVE STRENGTH ............ 32

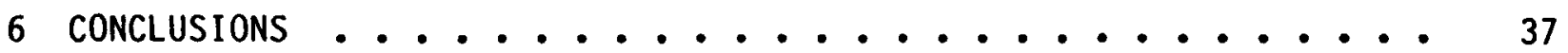

7 REFERENCES .................................... 38

APPENDIX A - VOLUMETRIC STRAIN-VERSUS-MEAN STRESS DATA FOR AVERY ISLAND CRUSHED SALT DURING QUASI-STATIC LOADING • • 39

APPENDIX B - VOLUMETRIC STRAIN-VERSUS-TIME DATA FOR AVERY ISLAND CRUSHED SALT DURING CONSOLIDATION (CREEP) $\ldots \ldots \ldots$ 
1-1. Variables and Their Levels in Current Experiment ....... 3

1-2. Test Matrix for Crushed Salt Experiment ........... 3

2-1. Sieve Stack and Grain Size Distributions for Crushed-Salt Experiment .................... 7

2-2. Summary of Initial Specimen Dimensions and Conditions . . . . 11

3-1. Calibration Results .................. 18

4-1. Summary of Results for the Crushed Salt Experiment . . . . . 22

5-1. Sign Convention Used in the Current Study to Estimate the Variable Effects .................. 29

5-2. Alias Pattern for the $2_{\text {IV }}^{4-1}$ Experiment ............ 31

5-3. Estimate of Variable Effects on the Creep Consolidation Bulk Density Ratio .................. 33

5-4. Estimate of Variable Effects on the Total Consolidation Bulk Density Ratio .................... 34

5-5. Estimate of Variable Effects on Unconfined Strength ...... 35 


\section{LIST OF FIGURES}

Figure Title

Page

2-1. Particle Size Distribution Curves for Crushed-Salt Experiment . .

2-2. Crushed-Salt Compaction Mold and Hammer .......... 10

3-1. Creep Test Machine Schematic .............. 14

3-2. MTS Universal Load Frame . . . . . . . . . . . 16

4-1. Volumetric Strain-Versus-Mean Stress for Avery Island Crushed Salt ....................... 24

4-2. Volumetric Creep Strain for Avery Island Crushed Salt at the Low Level of the Variable, Time . . . . . . . . . 25

4-3. Volumetric Creep Strain for Avery Island Crushed Salt at the High Level of the Variable, Time ............ 26 
1 INTRODUCTION

\subsection{BACKGROUND}

Backfilling the emplacement rooms and access drifts of a deep geologic nuclear waste repository in rock salt with native mine-run ore (crushed salt) is an attractive option under consideration by repository designers. The perceived benefits of the backfilling are (1) haulage and spoiling of the mine-run ore will be reduced significantiy; (2) repository permeability, at least locally, will be reduced if the backfill is consolidated significantly by creep deformations of the roof, floor, and rib of the room; and (3) pillar stresses will be reduced if some of the initial loads can be transferred to the backfill. If these benefits are proven, positive impacts on other phases of repository design may be realized. For instance, the long-term requirements of seals and plugs may be relaxed, and the closure of rooms by creep deformation may be reduced.

Assessment of the benefits of crushed-salt backfills requires a knowledge of the material properties and behavior. The material properties and behavior of interest are

- Deformation during loading (quasi-static)

- Deformation at constant load (creep)

- Permeability

- Strength.

The quasi-static and creep behavior is important in modeling the response of the backfill to stresses caused by creep deformation of the surrounding rock salt. Permeability and the decrease in permeability with consolidation and time are important to the overall sealing of the repository to limit radionuclide migration. Strength is important as it is an indicator of the relative ease with which the backfill can be mined should retrieval of the waste become necessary. The material properties and behavior can be determined from laboratory or field testing.

Several investigators [Hansen, 1976; Stinebaugh, 1979; Shor et al, 1981; and Holcomb and Hannum, 1982] have studied the behavior of crushed salt in laboratory experiments. A summary [IT Corporation, 1984] of these studies suggests that crushed-salt behavior is affected by several factors or variables, namely: 
- Salt impurities

- Grain size

- Grain size distribution

- Initial porosity

- Moisture content

- Stress state

- Load path

- Temperature

- Time.

Most of the past studies examined the effects of only one or perhaps several of the variables on the behavior of crushed salt. The objectives of this study are to determine statistically the main effects of four of these variables and the interactions among these variables relevant to two material properties, consolidation and strength. As a result, successive test matrices can be designed to examine only those variables that significantly affect the behavior of crushed salt.

\subsection{APPROACH AND SCOPE}

A laboratory experiment was developed using a class of statistical designs commonly known as two-level factorial designs [Box et al, 1978]. In these designs, two levels for each of a number of variables are selected; then, tests are performed with all possible combinations of levels and variables to evaluate the relative effects on a response. In this study, the variables are those given above, and the responses are the ratio of postcreep consolidation bulk density to precreep consolidation bulk density, $\rho_{f} / \rho_{j}$; the ratio of postcreep consolidation bulk density to the original undeformed bulk density, $\rho_{f} / \rho_{0}$; and the unconfined compressive strength, $C_{0}$. (Permeability rather than the ratios of bulk densities was the response of interest; however, the measurement of permeability on trial specimens of consolidated crushed salt revealed such large permeabilities that the RE/SPEC permeability apparatus could not be used).

Because of the large number of tests required to include all nine variables in this design $\left(2^{9}=512\right)$ and because of the limited time and money available, the full factorial design with nine variables was modified to a half-fraction design with four variables; i.e., time, grain size distribution, temperature, 
and moisture content. The variables and their respective levels are shown in Table 1-1. As a result of this modification, only eight tests were required for the experiment and are shown in Table 1-2.

The variable levels shown in Table 1-1, with the obvious exception of time, were selected to bracket expected levels at a typical salt repository. The $25^{\circ} \mathrm{C}$ temperature level is representative of temperatures expected in access rooms and at long times; while the $100^{\circ} \mathrm{C}$ level was selected to represent expected peak backfill temperatures in disposal rooms. The well-graded grain size distribution represented the expected distribution of mined crushed salt with one exception: grains larger than $9.5 \mathrm{~mm}$ were removed to stay within acceptable grain size-to-specimen size criterion. The uniform distribution was included as an extreme contrast; however, if results of testing on this material prove favorable, the distribution may become representative of the backfill in future designs. Additionally, the distributions were selected to have identical mean grain sizes to eliminate mean grain size effects. The dry level of moisture content is nearly representative of mine-run ore from a potential repository. The wet level (approximately 3 to 4 percent) was selected as the highest moisture content considered acceptable in an operating repository. Since long times are not practical, a high level was chosen to meet test schedules. The low level was then set to provide a sufficient time difference between levels for valid statistical inference.

In each of the eight tests, a crushed-salt specimen constructed of either uniform-graded or we11-graded grain sizes that had been either dried at $105^{\circ} \mathrm{C}$ or humidified $\left(85\right.$ percent relative humidity at $\left.26.5^{\circ} \mathrm{C}\right)$ for 24 hours was subjected to a hydrostatic compressive stress of $10 \mathrm{MPa}$ and permitted to consolidate (creep). The consolidation stage was performed at temperatures of either $25^{\circ} \mathrm{C}$ or $100^{\circ} \mathrm{C}$ and lasted either $3.5 \times 10^{3} \mathrm{~s}$ or $950 \times 10^{3} \mathrm{~s}$. Immediately after consolidation, an unconfined compression test was performed at a nominal strain rate of $1 \times 10^{-5} \mathrm{~s}^{-1}$ and a temperature of $20^{\circ} \mathrm{C}$.

Mean values for each response (bulk density ratios and unconfined compressive strength) were determined. In addition, for each response the four main variable effects and three two-variable interactions were calculated. Results show that the mean values for the bulk density ratios $\left(\rho_{f} / \rho_{j}\right.$ and $\left.\rho_{f} / \rho_{o}\right)$ and unconfined compressive strength are 1.08, 1.27, and 9.0 $\mathrm{MPa}$, respectively. The variables that significantly influence the bulk density ratio during creep are time and moisture content; while grain size distribution and, to a somewhat 
Table 1-1. Variables and Their Levels in Current Experiment

\begin{tabular}{|c|c|c|}
\hline Variable & Low Level & High Level \\
\hline Temperature $\left({ }^{\circ} \mathrm{C}\right)$ & 25 & 100 \\
\hline $\operatorname{Time}^{(\mathrm{a})}\left(10^{3} \mathrm{~s}\right)$ & 3.5 & 950 \\
\hline $\begin{array}{l}\text { Grain Size Distribution } \\
\text { (Based on Coefficient of Uniformity, } \\
\left.D_{60} / D_{10}\right)(b)\end{array}$ & 1 & 8 \\
\hline Moisture Content $(c)$ & D & $W$ \\
\hline
\end{tabular}

(a) After stress application.

(b) Ratio of diameters of grains for which 60 percent, $D_{60}$, and 10 percent, $D_{10}$, are smaller, respectively. See Table 2-1 and Figure 2-1 for actual size distribution.

(c) D-Dry, stored with desiccant; W-Wet, placed in an 85 percent relative humidity environment for 24 hours.

Table 1-2. Test Matrix for Crushed-Salt Experiment (a)

\begin{tabular}{|c|c|c|c|c|}
\hline \hline Run & $\begin{array}{c}\text { Temperature } \\
\left({ }^{\circ} \mathrm{C}\right)\end{array}$ & $\begin{array}{c}\text { Time } \\
\left(10^{3} \mathrm{~s}\right)\end{array}$ & $\begin{array}{c}\text { Grain Size } \\
\text { Distribution } \\
\left(D_{60} / D_{10}\right)\end{array}$ & Moisture \\
\hline 1 & 100 & 950 & 8 & W \\
2 & 25 & 950 & 8 & D \\
3 & 100 & 3.5 & 8 & D \\
4 & 25 & 3.5 & 8 & W \\
5 & 100 & 950 & 1 & D \\
6 & 25 & 950 & 1 & W \\
7 & 100 & 3.5 & 1 & D \\
8 & 25 & 3.5 & 1 & 8 \\
\hline
\end{tabular}

(a) All tests performed at a hydrostatic stress of $10 \mathrm{MPa}$. 
lesser degree, temperature have the greatest influence on the bulk density ratio for total consolidation. Strength is significantly influenced by time and moisture content and the two-factor interactions between either grain size distribution and time or temperature and moisture content.

\subsection{REPORT ORGANIZATION}

The remainder of the report is divided into five chapters and two appendixes. The next chapter describes the specimens used in this study, and the third chapter describes the test machines used and gives the test procedures. Test results are given in the fourth chapter, and the fifth chapter presents an analysis of the data. The sixth chapter gives the conclusions of this study and is followed by a list of cited references. Two appendixes conclude the report. Appendix $A$ gives the volumetric strain-versus-mean stress curves for each of the eight hydrostatic stress applications. Appendix $B$ gives the volumetric strainversus-time curves for the consolidation stages of the eight tests. 


\section{SPECIMENS}

\subsection{SALT CRUSHING AND SIZING}

The crushed salt for this experiment was fabricated by passing intact salt core fragments from the Avery Island Mine in Louisiana through a conventional flour mill. The mill, equipped with a set of adjustable grinding stones, permits a selection of aperture settings appropriate for the grain sizes required in the current study. After the salt was crushed, it was dried in a conventional oven at $105^{\circ} \mathrm{C}$ for 24 hours. To obtain grains of nominally equal size, the dried crushed salt was separated using a series of U.S. Standard Sieves. The sieves used in this procedure and their respective size of openings are given in Table 2-1. The uniform grains retained on each sieve were stored with a $\mathrm{CaSO}_{4}$ desiccant in jars until sufficient quantities of all grain sizes were obtained.

Accurate ratios of each uniform grain size were blended to form two distributions: one, a well-graded (WG) distribution having a coefficient of uniformity*, $C_{U}$, of 8 ; and the second, an extremely uniform-graded (UG) distribution with $C_{u}=1$. The grain size distribution for each blend is given in Table 2-1, and the curve is shown in Figure 2-1. Both distributions have an average grain size of $1 \mathrm{~mm}$. The maximum and minimum sizes for the well-graded distribution are $9.5 \mathrm{~mm}$ and $0.075 \mathrm{~mm}$, respectively, and for the uniform-graded distribution are $1.18 \mathrm{~mm}$ and $0.850 \mathrm{~mm}$, respectively. Each distribution was stored with desiccant in jars until required for the experiment.

\subsection{SPECIMEN PREPARATION}

The specimens for each test were prepared identically in all cases. A portion of crushed salt was removed from a desiccator jar and accurately weighed $(0.27 \mathrm{~kg}$ for the uniform-graded distribution and $0.36 \mathrm{~kg}$ for the well-graded distribution) with a Mettler P1200N balance having a resolution of $0.01 \mathrm{~g}$. If the specimen required wetting, the crushed salt was placed in a shallow dish

* The coefficient of uniformity, $c_{u}$, is defined as the ratio of the grain diameter at the 60 percent passing point to that at the 10 percent passing point on the gradation curve, or $C_{u}=D_{60} / D_{10}$. 
Table 2-1. Sieve Stack and Grain Size Distributions for Crushed-Salt Experiment

\begin{tabular}{|c|c|c|c|}
\hline \multirow{2}{*}{$\begin{array}{l}\text { Sieve } \\
\text { No. (a) }\end{array}$} & \multirow{2}{*}{$\begin{array}{r}\text { Sieve } \\
\text { Size } \\
(\mathrm{mm})\end{array}$} & \multicolumn{2}{|c|}{ Distribution - Percent Passing } \\
\hline & & $\begin{array}{l}\text { Uniform } \\
\text { Graded }\end{array}$ & $\begin{array}{c}\text { Well } \\
\text { Graded }\end{array}$ \\
\hline $3 / 8$ in & 9.500 & - & 100 \\
\hline $5 / 16$ in & 8.000 & - & 98 \\
\hline 3 & 6.300 & - & 96 \\
\hline 4 & 4.750 & - & 91 \\
\hline 5 & 4.000 & - & 87.5 \\
\hline 6 & 3.350 & - & 84 \\
\hline 7 & 2.800 & - & 80 \\
\hline 8 & 2.360 & - & 75 \\
\hline 10 & 2.000 & - & 70 \\
\hline 12 & 1.700 & - & 65 \\
\hline 14 & 1.400 & - & 60 \\
\hline 16 & 1.180 & 100 & 54 \\
\hline 18 & 1.000 & 50 & 50 \\
\hline 20 & 0.850 & 0 & 44 \\
\hline 30 & 0.600 & - & 34 \\
\hline 40 & 0.425 & - & 26 \\
\hline 60 & 0.250 & - & 15 \\
\hline 140 & 0.106 & - & 3 \\
\hline 200 & 0.075 & - & 0 \\
\hline
\end{tabular}

(a) U.S. Standard Sieves conforming to American Society for Testing and Materials (ASTM) Specification Ell. 


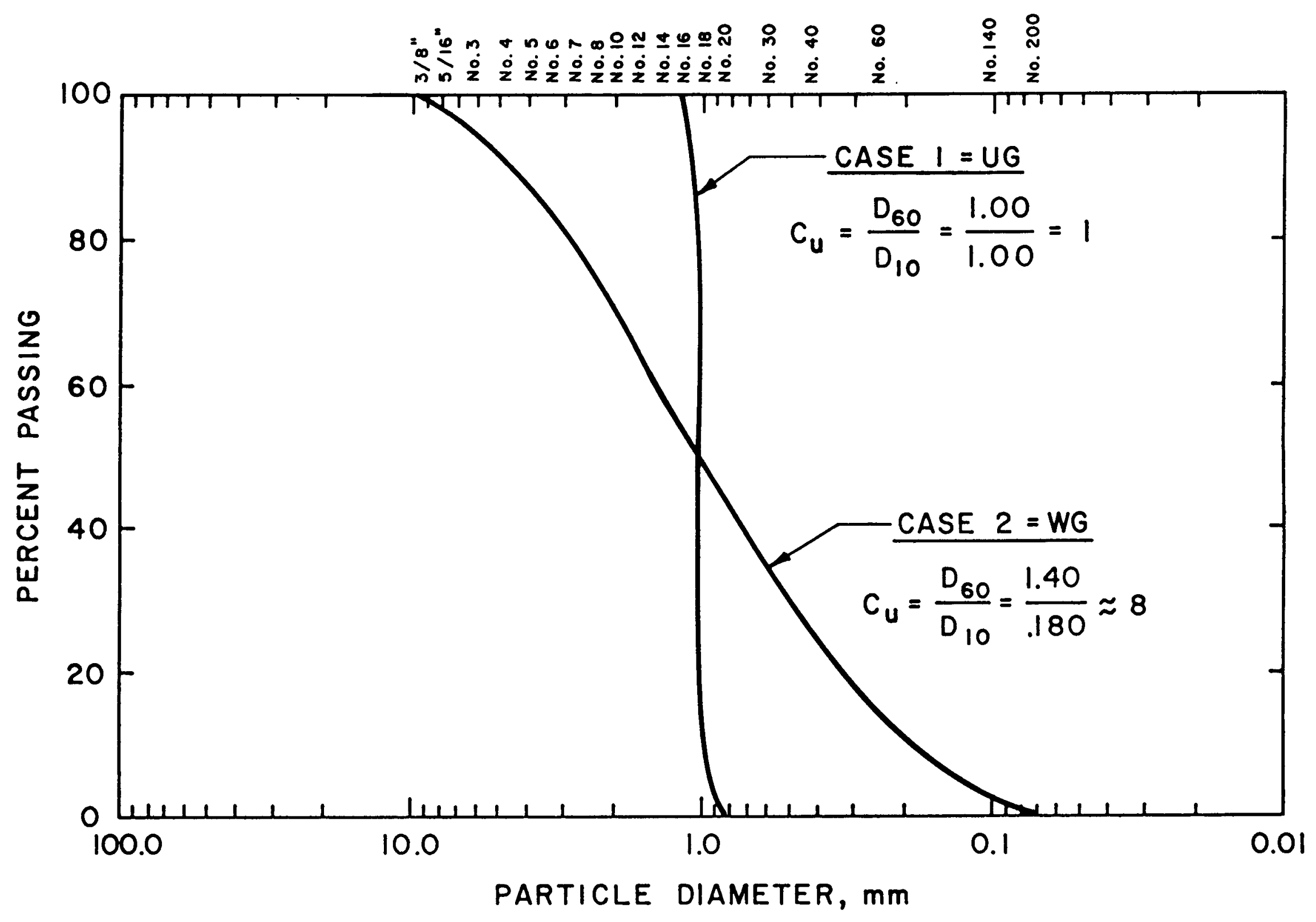

$x$
1
8
0
1
0
0
1
1
$w$
0
0

$\infty$

Figure 2-1. Particle Size Distribution Curves for Crushed-Salt Experiment 
that was then placed in a humidity chamber for 24 hours at 85 percent relative humidity and $26.5^{\circ} \mathrm{C}$. Upon removal from the chamber, the crushed salt was again weighed to determine the free moisture content. The moisture content of the wet salt was 3 to 4 percent by weight and does not include any water initially present either within crystals or on grain boundaries. The specimen was fabricated by compacting three equal layers of crushed salt in a viton jacket and mold affixed to a steel load platen as shown in Figure 2-2. The compactive effort for each layer was $494 \mathrm{~kJ} \cdot \mathrm{m}^{-3}$ and was attained by 25 repetitions of a $0.9-\mathrm{kg}$ hammer free-falling from a height of $0.15 \mathrm{~m}$. (Various combinations of repetitions, hammer weight, and height were used on trial specimens to obtain the highest initial density possible without significant crushing of individual grains.) A steel load platen was placed on the top of the compacted specimen, and the Viton jacket was secured to this upper platen with lock wire.

The initial dimensions of each specimen were determined indirectly following compaction. The length was determined by measuring the total length of the specimen-platen assembly and subtracting the combined lengths of the platens. The diameter was determined by subtracting two thicknesses of the Viton jacket from the inside diameter of the mold. Nominal dimensions for all specimens were $50-\mathrm{mm}$ diameters by $100-\mathrm{mm}$ lengths. Each specimen was assigned an identification number and logged into the RE/SPEC computerized core inventory. A typical identification number is

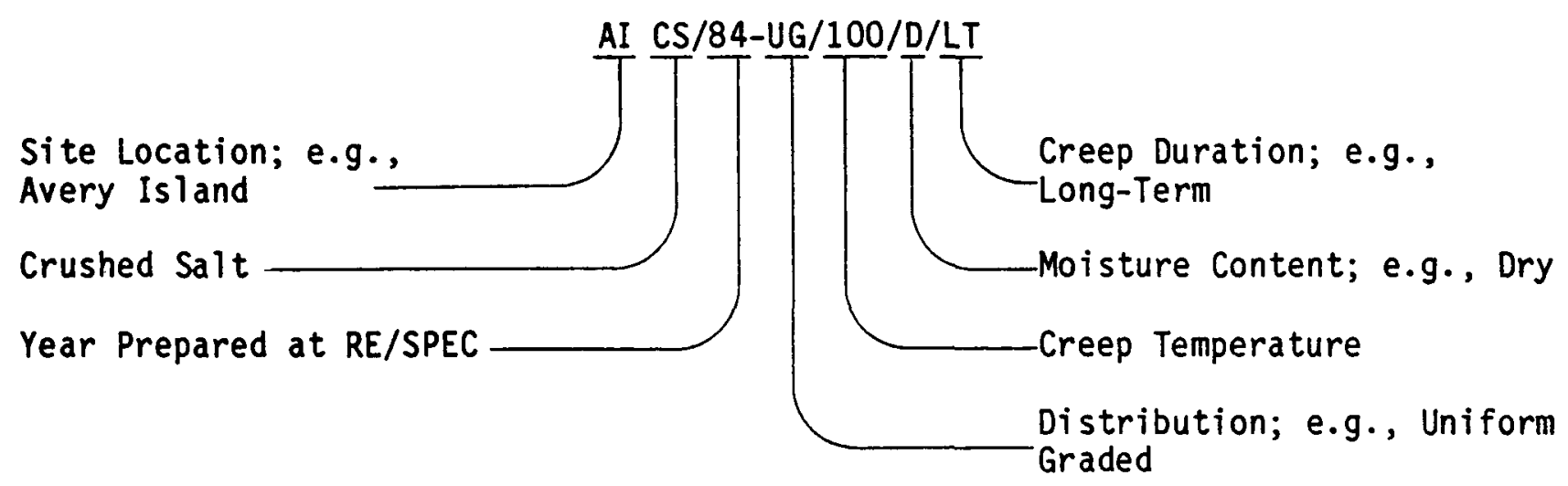

Table 2-2 summarizes the initial dimensions and conditions for each specimen. 


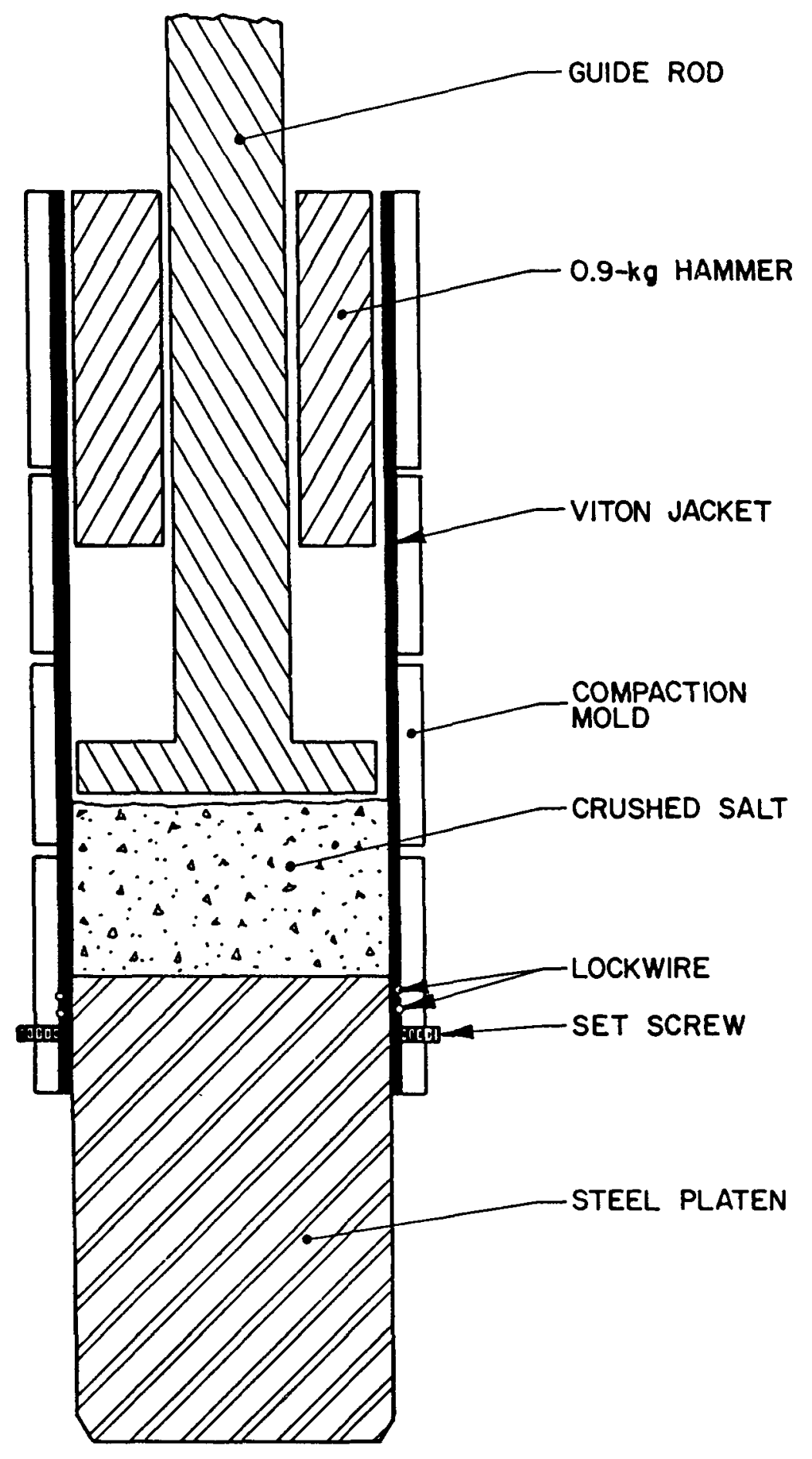

Figure 2-2. Crushed-Salt Compaction Mold and Hammer 
Table 2-2. Summary of Initial Specimen Dimensions and Conditions

\begin{tabular}{|l|c|c|c|c|c|c|}
\hline \hline $\begin{array}{c}\text { Specimen } \\
\text { I.D. }\end{array}$ & $\begin{array}{c}\text { Length } \\
(\mathrm{mm})\end{array}$ & $\begin{array}{c}\text { Diameter } \\
(\mathrm{mm})\end{array}$ & $\begin{array}{c}\text { Weight } \\
(\mathrm{kg})\end{array}$ & $\begin{array}{c}\text { Density } \\
\text { Dry, } \rho_{0} \\
\left(\mathrm{~kg} / \mathrm{m}^{3}\right)\end{array}$ & Porosity(a) & $\begin{array}{c}\text { Moisture }(\mathrm{b}) \\
\text { Content } \\
(\%)\end{array}$ \\
\hline AICS/84-WG/100/W/LT & 109.6 & 51.2 & 0.36 & 1595 & 0.27 & 3.2 \\
AICS/84-WG/25/D/LT & 105.5 & 51.2 & 0.36 & 1660 & 0.24 & - \\
AICS/84-WG/100/D/ST & 107.9 & 51.2 & 0.36 & 1620 & 0.26 & - \\
AICS/84-WG/25/W/ST & 108.4 & 51.2 & 0.36 & 1615 & 0.26 & 3.3 \\
AICS/84-UG/100/D/LT & 100.0 & 51.2 & 0.27 & 1310 & 0.40 & - \\
AICS/84-UG/25/W/LT & 101.6 & 51.2 & 0.27 & 1290 & 0.41 & 4.3 \\
AICS/84-UG/100/W/ST & 104.4 & 51.2 & 0.27 & 1255 & 0.43 & 4.3 \\
AICS/84-UG/25/D/ST & 104.5 & 51.2 & 0.27 & 1255 & 0.43 & - \\
\hline \hline
\end{tabular}

(a) Assumes a theoretical salt density of $2190 \mathrm{~kg} / \mathrm{m}^{3}$.

(b) Based on dry weight. 


\subsection{POST-TEST DISPOSITION}

After each specimen has been tested, it is sealed in a plastic bag with an identification tag and stored in the RE/SPEC core facilities. An inventory record of specimens is also kept in the RE/SPEC offices. 


\section{TESTING}

The hydrostatic consolidation tests were conducted using two triaxial machines. The machines were designed and constructed by Dr. W. R. Wawersik of Sandia National Laboratories. These machines have been described in a previous publication [Hansen and Mellegard, 1980] and have the distinctive capability of measuring volumetric changes during a hydrostatic consolidation creep test. The unconfined compression tests were conducted using a computer-controlled, universal load frame designed by MTS Systems Corporation.

\subsection{LOAD FRAMES}

\subsubsection{Consolidation Machines}

Figure 3-1 presents a cross section of a typical load frame for hydrostatic consolidation creep testing with prominent components labeled for reference. The machines use a double-ended, triaxial pressure vessel that accommodates a 50-mn-diameter cylindrical specimen having a length-to-diameter ratio of $L: D=2$. A hydraulic cylinder bolted on the load frame drives the loading piston, which applies axial compressive force to the specimen. Confining pressure is applied to the jacketed specimen by pressurizing the sealed vessel chamber with silicone oil. A dilatometer system maintains constant confining pressure and provides volumetric measurements.

The two testing machines can apply confining pressures up to $70 \mathrm{MPa}$. One machine can apply a compressive axial load up to $270 \mathrm{kN}$, while the other has a greater axial load capability and can apply a load up to $530 \mathrm{kN}$. The heating system, including seals on the pressure vessel, can maintain specimen temperatures up to $200^{\circ} \mathrm{C}$.

The test frame and control panel house the accumulators, hydraulic pumps, pressure intensifiers, temperature controllers, and confining pressure controllers for both test frames. The panels contain digital meters that display the output of the transducers. The temperature controller gives a digital output of the temperature. Mechanical pressure gages give readings of the nitrogen pressure in the accumulator and the oil pressure in the hydraulic cylinder. 


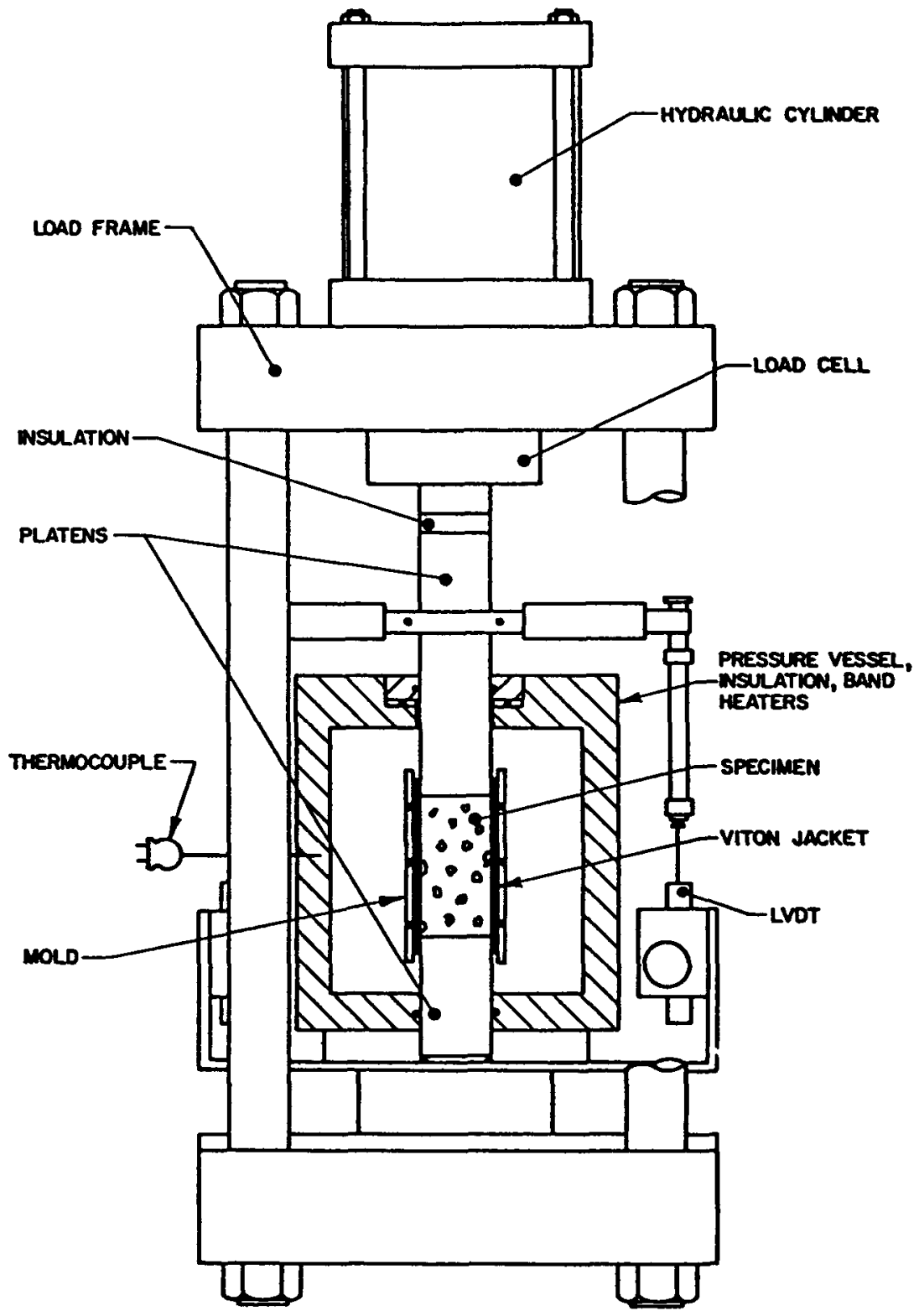

Figure 3-1. Creep Test Machine Schematic 


\subsubsection{MTS Universal Load Frame}

Figure 3-2 presents the characteristic two-post design of the MTS universal load frame. A hydraulic cylinder located in the base of the machine can apply $500 \mathrm{kN}$ of force (tensile/compressive) to a specimen. The movable crosshead allows for a wide range of specimen lengths.

The machine is completely servocontrolled. A Digital Equipment Corporation (DEC) LSI-11/23 microcomputer (programmable in BASIC) provides closed loop test control in either load or displacement feedback mode.

\subsection{INSTRUMENTATION}

\subsubsection{Consolidation Machines}

Axial force is measured by a load cell in the load train outside the pressure vessel, while confining pressure is measured by a pressure transducer in the line between the intensifier and the pressure vessel. Temperature is measured by a thermocouple in the wall of the pressure vessel. The relationship between specimen temperature and that recorded by this thermocouple has been determined by calibration runs at several temperatures that span the operating range. Axial deformation in the specimen is measured by two Linear Variable Differential Transformers (LVDTS) mounted outside the pressure vessel. They monitor displacement of the loading piston relative to the bottom of the pressure vessel. Lateral deformation is measured using a dilatometer. With this technique, lateral deformation is determined at fixed pressure by measuring the volume of oil that the intensifier replaces in the pressure vessel, and then compensating for the axial deformation measured by the LVDTs. A rotary potentiometer is mounted on the intensifier shaft to provide a signal that is proportional to the volume of oil that is replaced in the pressure vessel.

Data collected consist of axial force, confining pressure, axial displacement, volumetric displacement, and temperature. A COMTEL Corporation DATAC 600 System and a Data General Corporation NOVA 2 minicomputer provide control for logging data and converting transducer signals to engineering units. 


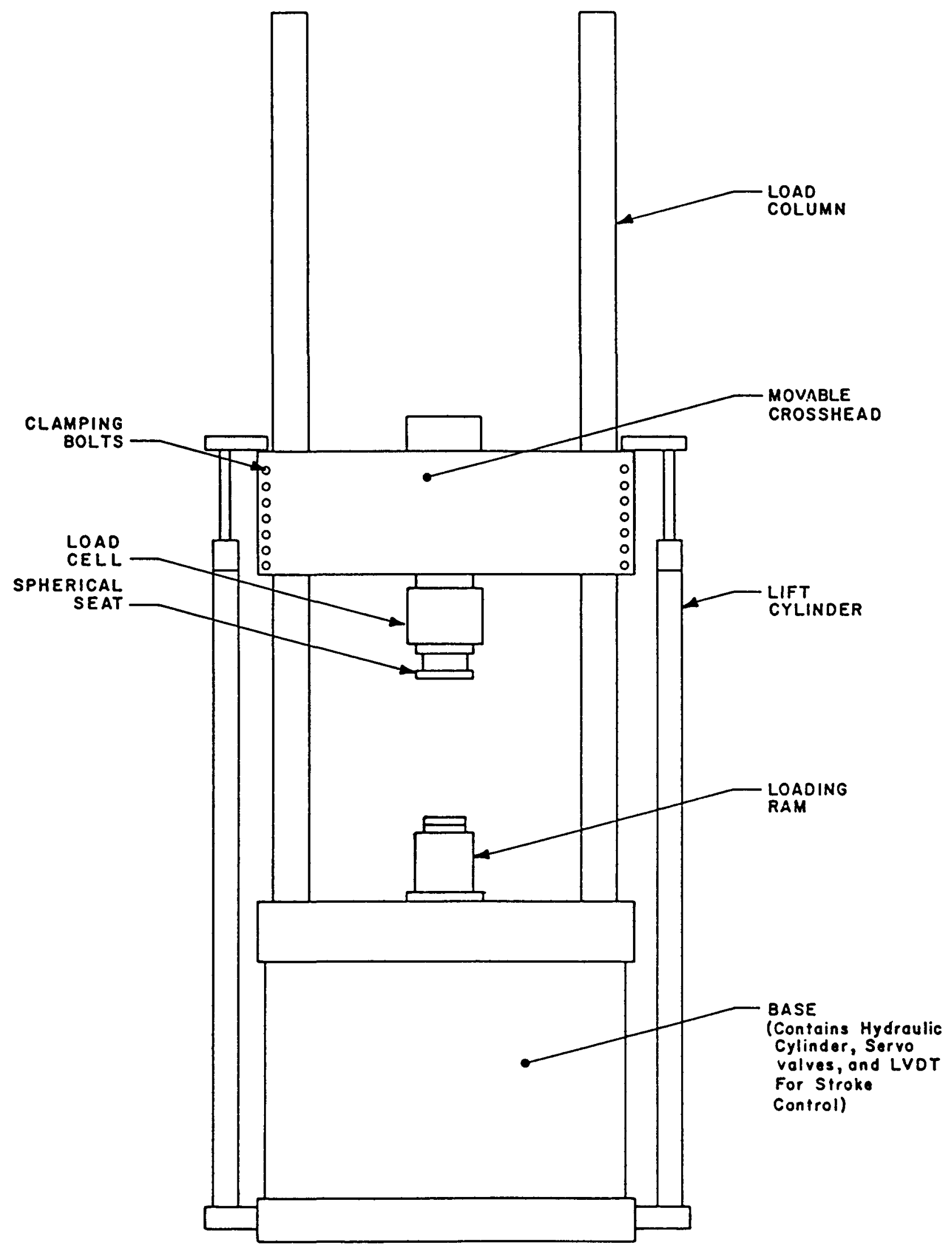

Figure 3-2. MTS Universal Load Frame 


\subsubsection{MTS Universal Load Frame}

Only axial force was measured in the unconfined compression tests and is measured by a load cell equipped with a spherical seat. A control console houses the signal conditioning for the transducer and interfaces with a DEC LSI-11/23 microcomputer to provide data acquisition.

\subsection{CALIBRATION}

The transducers used to collect data are calibrated using standards traceable to the National Bureau of Standards. Table 3-1 summarizes the results of the calibration.

\subsection{CONTROL}

\subsubsection{Consolidation Machines}

Temperature is controlled with a controller having a manual set point that regulates power to the band heaters on the vessel. The thermocouple in the pressure vessel wall supplies the feedback signal. The specimen temperature is maintained constant within $0.2^{\circ} \mathrm{C}$. Confining pressure is controlled by inputting the pressure transducer signal to a unit that contains two manual set points. These set points are adjusted to maintain the confining pressure constant within $20 \mathrm{kPa}$. When a set point is reached, the controller signals the intensifier to advance or retreat, depending upon whether the lower or upper set point has been reached. Axial load is controlled manually by metering gas into or out of a nitrogen-charged bladder accumulator. The deadband on load is $1.0 \mathrm{kN}$, and for 50-mm-diameter specimens, gives a deadband on axial stress of $0.50 \mathrm{MPa}$.

\subsubsection{MTS Universal Load Frame}

The unconfined compression tests require only the control of the axial strain rate. Programmable control of the strain rate is provided by an LVDT mounted in the load actuator at the base of the load frame, a control console housing feedback and valve driver modules for the hydraulics, and a DEC LSI-11/23 microcomputer. 
Table 3-1. Calibration Results

\begin{tabular}{|c|c|c|c|}
\hline Measurement & Range & Accuracy & Resolution \\
\hline \multicolumn{4}{|l|}{ CONSOLIDATION MACHINES } \\
\hline Axial Strain (Percent) & $0-25$ & 0.125 & 0.0025 \\
\hline Lateral Strain (Percent) & $0-5$ & $0.01^{(a)}$ & $0.0004^{(a)}$ \\
\hline $\begin{array}{l}\text { Axial Load }(k N) \\
\text { Machine } 1 \\
\text { Machine } 2\end{array}$ & $\begin{array}{l}0-530 \\
0-270\end{array}$ & $\begin{array}{l}0.75 \\
0.95\end{array}$ & $\begin{array}{l}0.05 \\
0.03\end{array}$ \\
\hline Confining Pressure (MPa) & $0-70$ & 0.04 & 0.007 \\
\hline Temperature $\left({ }^{\circ} \mathrm{C}\right)$ & $25-200$ & $2.0^{(b)}$ & 0.02 \\
\hline MTS UNIVERSAL LOAD FRAME & & & \\
\hline Axial Load (kN) & $0-50$ & 0.05 & $0.01(c)$ \\
\hline
\end{tabular}

(a) Accuracy and resolution determined at zero strain.

(b) Manufacturer's specified accuracy.

(c) 14-bit analog-to-digital converter with one bit to denote sign. 


\subsection{TEST PROCEDURES}

\subsubsection{Consolidation Tests}

Consolidation tests are performed in two stages. In the first stage, hydrostatic stress is applied quasi-statically until the target stress is reached. This is followed by the second stage, the creep stage, in which consolidation occurs with time. The discussion below describes the procedure for both stages.

Jacketed specimens of crushed salt are placed in a pressure vessel that is subsequently filled with silicone oil. The vessel is sealed and placed in a load frame. The specimen is heated to the target temperature and allowed to stabilize for 12 hours. Following stabilization, a hydrostatic stress is applied by the operator. Since the vessel design features axial and confining pressure hydraulics that are decoupled, the hydrostatic stress application is performed quasi-statically by increasing the confining pressure while simultaneously applying an axial force. Pressure increments of $0.5 \mathrm{MPa}$ are used to prevent large deviatoric stresses. The stress application stage requires about 20 minutes to complete, resulting in a nominal load rate of $1 \times 10^{-2} \mathrm{MPa} \cdot \mathrm{s}^{-1}$. When the target hydrostatic creep stress of $10 \mathrm{MPa}$ is reached, the dilatometer servosystem is actuated to maintain constant confining pressure. Axial load is maintained during the creep stage with a nitrogen-charged accumulator. Adjustment of the load is made periodically by the operator by either adding nitrogen to or venting nitrogen from the accumulator. During the test, data are logged according to one of two criteria. First, if the specimen length changes by a prescribed amount since the last data were logged, data are logged again. If, however, the specimen length changes by less than the prescribed amount over a time selected by the operator, data are logged at the end of this time period. When the desired creep duration is reached, the hydrostatic stress is removed in decrements of $0.5 \mathrm{MPa}$ at a rate of $1 \times 10^{-2} \mathrm{MPa} \cdot \mathrm{s}^{-1}$.

\subsubsection{Unconfined Compression Tests}

Each consolidated specimen is placed in the MTS universal load frame immediately after removal from the pressure vessel. In load control, a small preload is applied to the specimen. The control program is initiated by the 
operator and requires input of the specimen dimensions. Control is then switched to the stroke transducer (LVDT), and the specimen is loaded at a nominal axial strain rate of $1 \times 10^{-5} \mathrm{~s}^{-1}$ to failure. The computer identifies failure as a 10 percent decrease in load below the peak load carried by the specimen. Control is switched back to the load cell, and the specimen is quickly unloaded. The unconfined compressive strength is calculated from the post-consolidation specimen dimensions and the peak load and is printed at the control terminal. 


\section{RESULTS}

\subsection{CONSOLIDATION TESTS}

\subsubsection{Quasi-Static Behavior}

The quasi-static volumetric strain data are used to determine the initial density of each specimen before creep consolidation occurs by

$$
\rho_{i}=\frac{\rho_{0}}{1-\varepsilon_{V}}
$$

where $\rho_{j}$ and $\rho_{0}$ are the initial density before creep and the original undeformed s.pecimen density (Table 2-2), respectively, and $\varepsilon_{v}$ is the volumetric strain that occurred during quasi-static application of the hydrostatic load. Table 4-1 gives the original density and initial density for each specimen as calculated from Equation 4-1. The volumetric strain, $\varepsilon_{v}$, can be related to the principal engineering strains, $\varepsilon_{1}$ and $\varepsilon_{2}$, by

$$
\varepsilon_{v}=\varepsilon_{1}+2 \varepsilon_{2}+\varepsilon_{1} \varepsilon_{2}^{2}-2 \varepsilon_{1} \varepsilon_{2}-\varepsilon_{2}^{2}
$$

Equation 4-2 assumes that $\varepsilon_{2}=\varepsilon_{3}$ (true for traditional triaxial test equipment) and includes second and third order terms important in large-strain determination. For true hydrostatic loading assuming material isotropy, $\varepsilon_{1}=\varepsilon_{2}=\varepsilon_{3}$. Thus, Equation 4-2 can be rewritten as

$$
\varepsilon_{v}=3 \varepsilon_{1}+\varepsilon_{1}^{3}-3 \varepsilon_{1}^{2}
$$

and only $\varepsilon_{1}$ (i.e., the axial strain which is equal to the change in specimen length, $\Delta L$, divided by the original specimen length, $L_{0}$ ) needs to be measured. The isotropy assumption will be discussed in the next section.

Plots of quasi-static volumetric strain as calculated from Equation 4-3 versus mean stress for each test are given in Appendix A. Mean stress is calculated simply by 
Table 4-1. Summary of Results for the Crushed-Salt Experiment

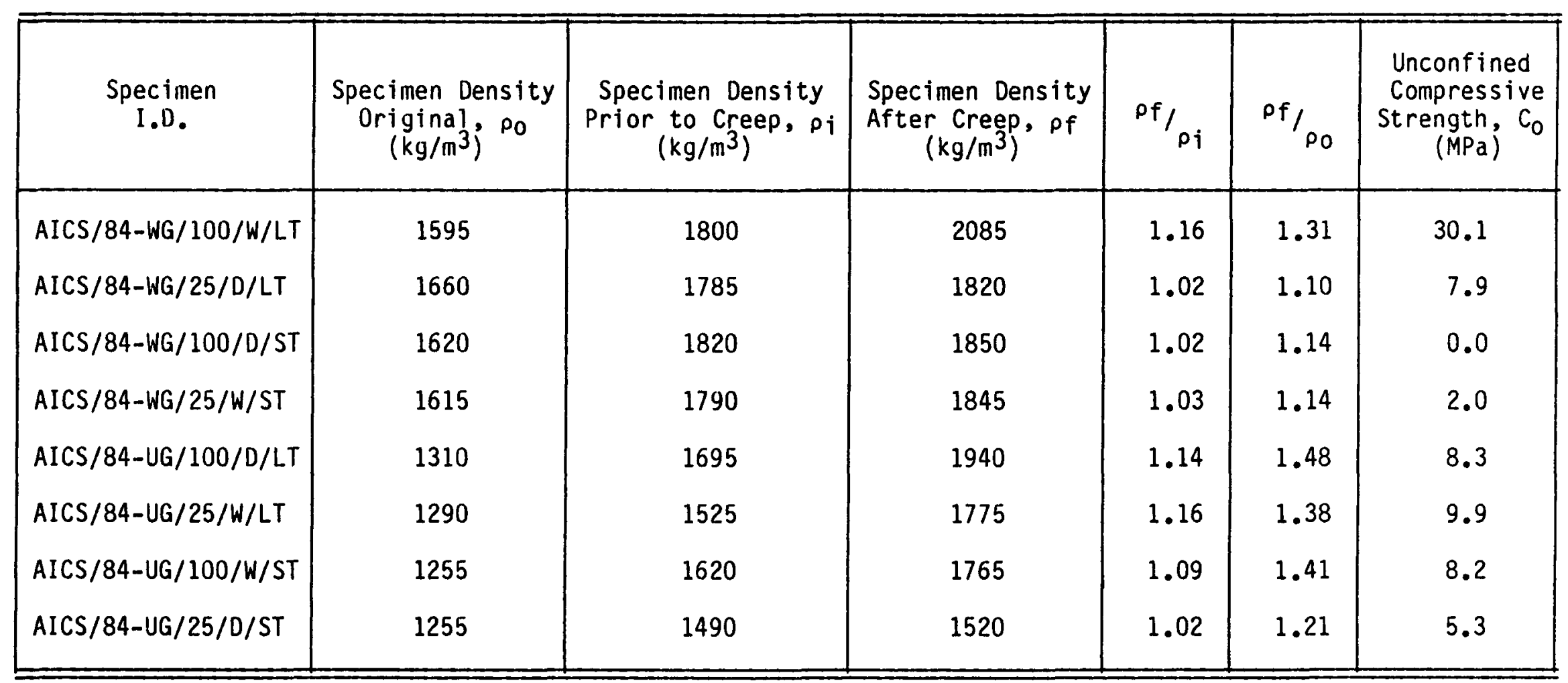




$$
\sigma_{\mathrm{m}}=\frac{\sigma_{1}+2 \sigma_{2}}{3}
$$

where $\sigma_{1}$ and $\sigma_{2}$ are the axial stress and confining pressure, respectively. For comparative purposes, the volumetric strain-versus-mean stress curves are plotted in Figure 4-1. It is apparent, at least qualitatively, that larger volumetric strains occur at the high level of temperature $\left(i . e ., 100^{\circ} \mathrm{C}\right.$ ) and at the low level of grain size distribution (i.e., $c_{u}=1$ ).

\section{1 .2 Creep}

During the creep stage, the lateral strain, $\varepsilon_{2}$, is determined directly from volume measurements of oil replaced in the vessel by

$$
\varepsilon_{2}=1-\sqrt{1-\frac{1}{\left(L_{i}-\Delta L\right) D_{i}^{2}}\left\{\frac{4 \Delta V}{\pi}+\Delta L\left(D_{p}^{2}-D_{i}^{2}\right)\right\}}
$$

where

$$
\begin{aligned}
\varepsilon_{2}= & \text { Lateral engineering strain, } \Delta D / D_{i} \\
L_{i}, & D_{i}= \\
\Delta L= & \text { Initial specimen length and diameter before creep } \\
\Delta V= & \text { Volume of oil replaced in the vessel corrected for } \\
& \text { temperature } \\
D_{p}= & \text { Diameter of the loading platen }
\end{aligned}
$$

The validity of the isotropy assumption in the previous section can be checked by comparing the volumetric strains as calculated using Equation 4-3 and those calculated using Equation 4-2. If the assumption is correct, both equations should yield identical volumetric strains. Appendix $B$ gives plots of volumetric creep strain using both equations for each of the eight tests. In general, the agreement between the two equations is good, thereby validating the assumption of isotropy.

Figures 4-2 and 4-3 give plots of volumetric creep strain (Equation 4-2) for the short- and long-term tests, respectively. The main effects of the 


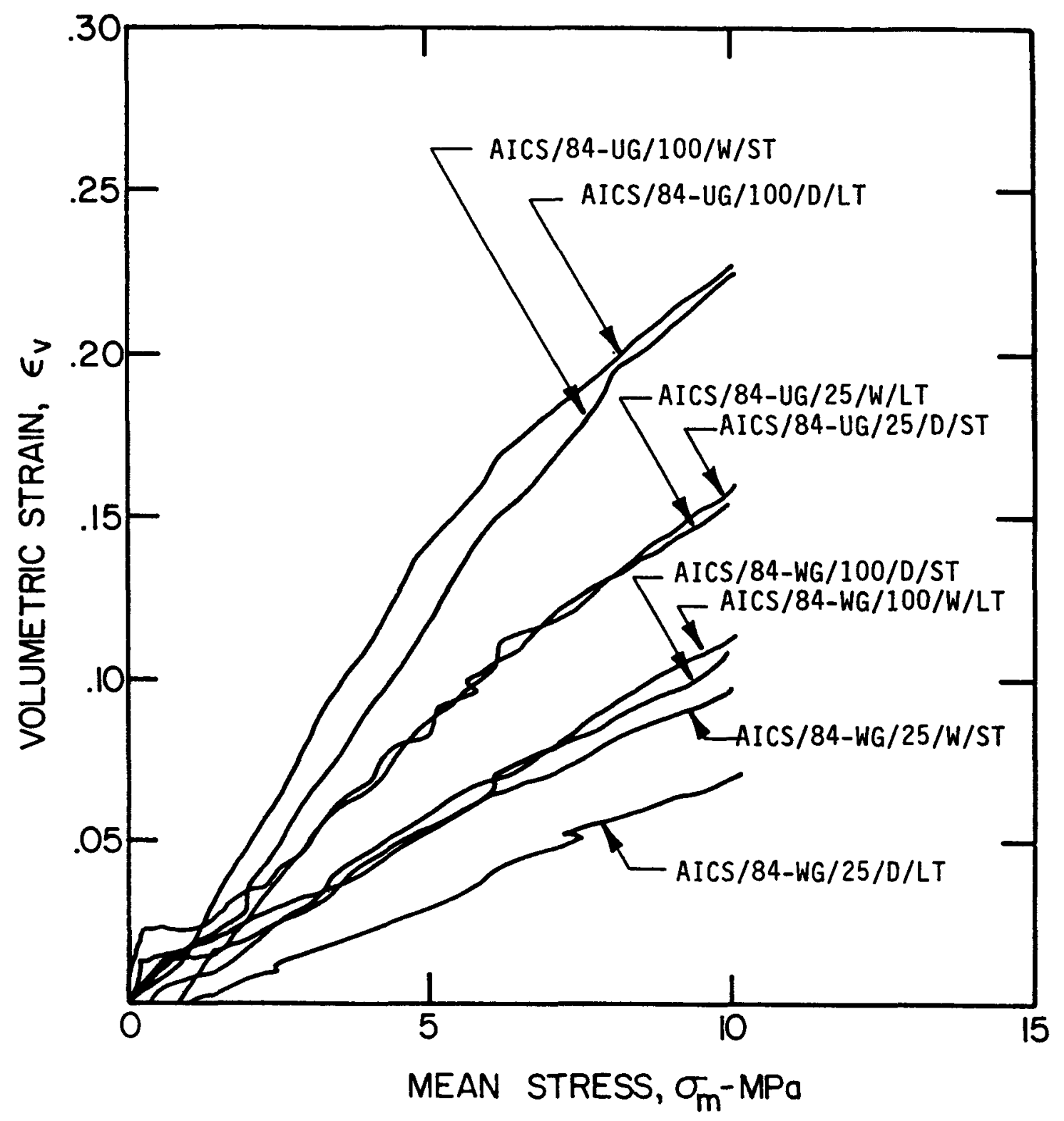

Figure 4-1. Volumetric Strain-Versus-Mean Stress for Avery Island Crushed Salt 


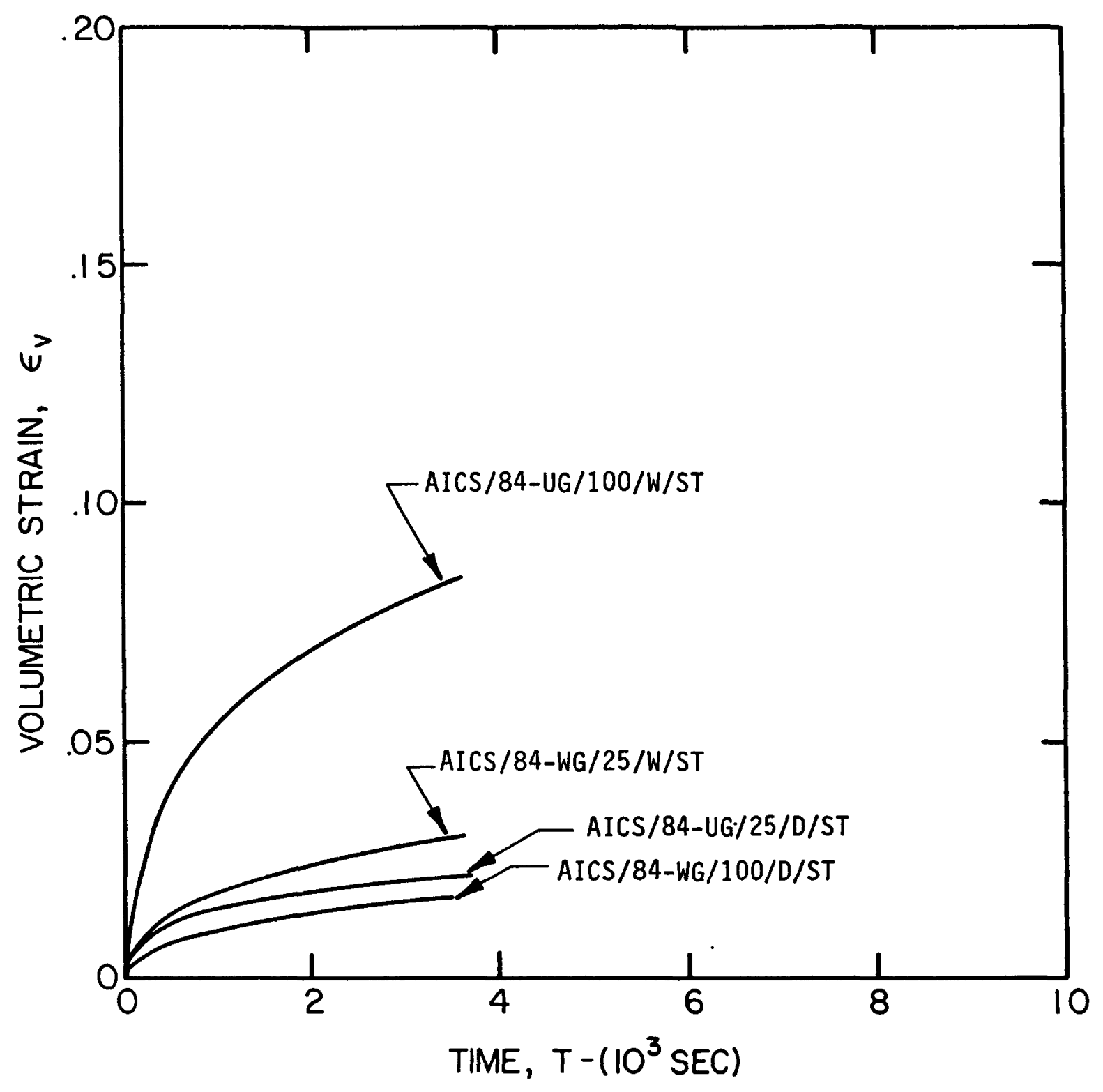

Figure 4-2. Volumetric Creep Strain for Avery Island Crushed Salt at the Low Level of the Variable, Time 


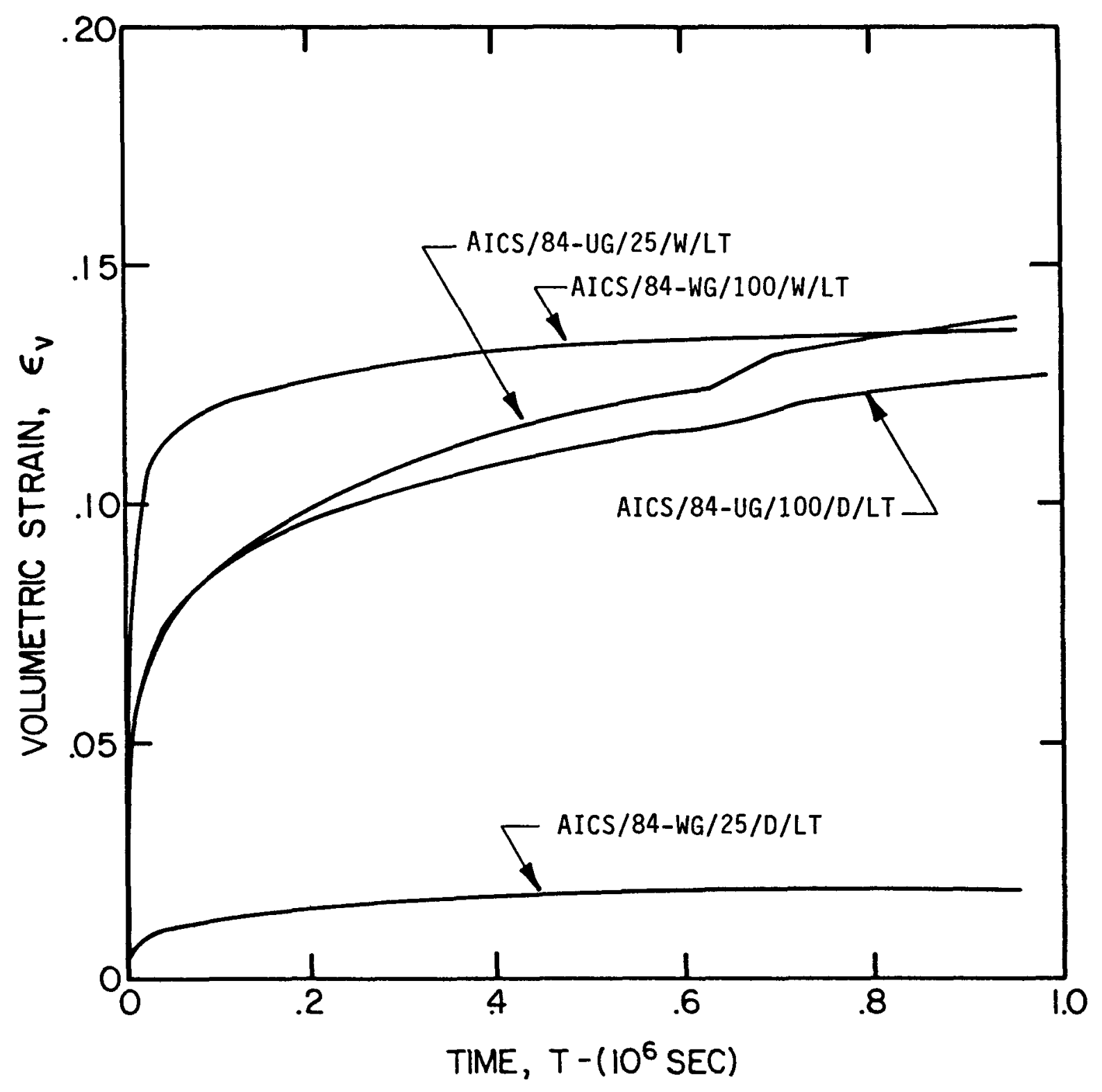

Figure 4-3. Volumetric Creep Strain for Avery Island Crushed Salt at the High Level of the Variable, Time 
variables are not as clear as before, and variable interactions are probably more important. The density, of, is determined after the creep stage using Equations 4-1 and 4-2 and substituting $\rho_{f}$ for $\rho_{j}, \rho_{j}$ for $\rho_{0}$, and the volumetric creep strain for $\varepsilon_{v}$. The final density for each specimen and the ratios $\rho_{f} / \rho_{j}$ and $\rho_{f} / \rho_{0}$ are given in Table 4-1. These final densities agree well with density measurements made after the specimens are removed from the pressure vessel. It should also be noted from Table 4-1 and the appendixes that most of the consolidation occurs during the application of hydrostatic load.

\subsection{UNCONFINED COMPRESSION TESTS}

The results of the unconfined compression tests are also given in Table 4-1. The values of $C_{0}$ are based on the dimensions of the specimen after consolidation and are not corrected for shape change during the unconfined test. All values are below $10 \mathrm{MPa}$ with the exception of one value $(30.1 \mathrm{MPa})$ determined for the wet, well-graded specimen consolidated at $100^{\circ} \mathrm{C}$, long term. This value is higher than the average value $(23.1 \mathrm{MPa})$ reported by Hansen and Mellegard [1980] for intact Avery Island salt. 


\section{ANALYSIS}

\subsection{DISCUSSION}

The number of runs required by a full factorial design at two levels increases geometrically with the number of variables or factors to be studied. For instance, if the influence of nine variables is to be assessed, as is the case for crushed salt, $2^{9}=512$ runs or tests would be required. From these runs, 512 statistics could be calculated which estimate main effects, as well as interaction effects. In an effort to save both time and money and because full factorial designs tend to be inherently redundant, a half-fraction factorial design approach [Box et al, 1978] considering only four variables; i.e., grain size distribution, temperature, time, and moisture content, was used to analyze the results presented in the previous section. Although no information is obtained for the other five variables (i.e., impurities, grain size, initial porosity, stress state, and load path), any of these variables can be added at a later time without affecting the design or analysis. In addition, if variables currently under study have no distinguishable effect, they can be deleted in subsequent experiments.

A half-fraction for four variables requires eight runs or tests. The eight runs are chosen by writing a full factorial design for the first three variables (in this case, grain size distribution, temperature, and moisture content) using minus and plus signs to denote the low and high levels of each variable, respectively. Table 5-1 shows the signs for the first three variables in columns 1 through 3. The level of the remaining variable, time, is selected for each run by determining the sign of the algebraic product of the signs in the first three columns in Table 5-1. For instance in run one, the sign of the algebraic product is positive; i.e., $(t)=(+) \times(+) \times(+)$, and thus, the high level $\left(950 \times 10^{3} \mathrm{~s}\right)$ for the variable, time, is required for run one. Column 4 gives the signs for the remaining runs.

The half fraction can also be designated by $2{ }^{4-1}$ : the notation implies that four variables at two levels are considered, but that only $2^{4-1}=8$ runs are employed. The subscript IV gives the resolution of the design and indicates the confounding pattern. Confounding occurs when all the runs of a full factorial are not performed. To define the confounding pattern, Table 5-1 is used and three-factor and higher order interactions are assumed to be negligible. Product columns of plus and minus signs are determined for each 
Table 5-1. Sign Convention Used in the Current Study to Estimate the Variable Effects

\begin{tabular}{|c|c|c|c|c|c|c|c|c|c|c|}
\hline \multirow[b]{2}{*}{ Run } & \multicolumn{4}{|c|}{ Design Variable } & \multicolumn{3}{|c|}{ Variable Interactions } & \multicolumn{3}{|c|}{ Response } \\
\hline & $\begin{array}{c}\text { Grain } \\
\text { Size } \\
\text { Distribution } \\
\text { (1) }\end{array}$ & $\begin{array}{c}\text { Temperature } \\
\text { (2) }\end{array}$ & $\begin{array}{l}\text { Moisture } \\
\text { Content } \\
\text { (3) }\end{array}$ & $\begin{array}{r}\text { Time } \\
(4)\end{array}$ & $\begin{array}{c}1 \times 2= \\
3 \times 4 \\
(5)\end{array}$ & $\begin{array}{c}1 \times 3= \\
2 \times 4 \\
(6)\end{array}$ & $\begin{array}{c}1 \times 4= \\
2 \times 3 \\
(7)\end{array}$ & $\begin{array}{c}\rho f / \rho_{j} \\
(8)\end{array}$ & $\begin{array}{l}\rho f / \rho_{0} \\
(9)\end{array}$ & $\begin{array}{l}\mathrm{C}_{\mathrm{O}} \\
(\mathrm{MPa}) \\
(10)\end{array}$ \\
\hline 1 & + & + & + & + & + & + & + & 1.16 & 1.31 & 30.1 \\
\hline 2 & + & - & - & + & - & - & + & 1.02 & 1.10 & 7.9 \\
\hline 3 & + & + & - & - & + & - & - & 1.02 & 1.14 & 0.0 \\
\hline 4 & + & - & + & - & - & + & - & 1.03 & 1.14 & 2.0 \\
\hline 5 & - & + & - & + & - & + & - & 1.14 & 1.48 & 8.3 \\
\hline 6 & - & - & + & + & + & - & - & 1.16 & 1.38 & 9.9 \\
\hline 7 & - & + & + & - & - & - & + & 1.09 & 1.41 & 8.2 \\
\hline 8 & - & - & - & - & + & + & + & 1.02 & 1.21 & 5.3 \\
\hline
\end{tabular}


two-factor interaction by multiplication of the individual elements of the columns for the two factors (variables) to be studied. For example, the signs in Column 5; i.e., the interaction between grain size distribution and temperature, are determined by multiplying the elements in Columns 1 and 2 . If this is done for all interactions, one sees that the sign sequence in the product columns for $1 \times 2$ is equal to $3 \times 4,1 \times 3$ is equal to $2 \times 4$, and $1 \times 4$ is equal to $2 \times 3$. This means these interaction effects are confounded or are alias of one another. If one of these interactions, such as the interaction between grain size distribution and temperature, is found to be important, then the only conclusion one can reach is that either the interaction between grain size distribution and temperature or the interaction between moisture content and time has influence on the response. Thus, the interactions must be considered together and not separately. Table 5-2 shows the alias pattern for the two-factor interactions of this study. In general for a design of resolution IV, main effects and two-factor interactions are not confounded; but two-factor interactions are confounded with other two-factor interactions.

Eight statistics can be calculated for each response measured in the experiment. The statistics are

- One mean

- Four main effects

- Three two-factor interactions.

The mean response is calculated by summing the values in Columns 8, 9, and 10, respectively, and dividing by the number of runs; i.e., eight. The main effects and the two-factor interactions are calculated by algebraically summing the values in Columns 8,9 , and 10 , respectively, using the signs in the product Columns 1 through 7 and dividing by the number of runs divided by two; i.e., four. For example, the main effect of grain size distribution on the creep consolidation bulk density ratio, $\rho_{f} / \rho_{j}$, is -0.045 and is calculated from

$$
-0.045=\frac{\{+1.16+1.02+1.02+1.03-1.14-1.16-1.09-1.02\}}{4}
$$

The statistics for each response are presented below. 
Table 5-2. Alias Pattern for the $2_{\text {IV }}^{4-1}$ Experiment

\begin{tabular}{|l|l|}
\hline \multicolumn{1}{|c|}{ Two-factor Interaction } & \multicolumn{1}{|c|}{ Alias } \\
\hline Grain Size Distribution x Temperature & Moisture Content $\times$ Time \\
Grain Size Distribution x Moisture Content & $\begin{array}{l}\text { Temperature } \times \text { Time } \\
\text { Temperature } \times \text { Moisture Content } \\
\text { Grain Size Distribution x Time }\end{array}$ \\
\hline
\end{tabular}




\subsection{BULK DENSITY RATIO FOR CREEP CONSOLIDATION}

The influence of the four variables on the creep consolidation bulk density ratio, $\rho_{f} / \rho_{j}$, is shown in Table 5-3 in terms of the eight statistics. The relative magnitude and not the sign or absolute magnitude is important. The effect of the variable, time, is the most important and is about twice that of either grain size distribution or temperature. Moisture content does have some influence on the consolidation but not quite as much as time. All two-factor interaction effects are only one-fourth to one-third the main effects and as such are insignificant. It is not surprising that the consolidation is influenced by time, since consolidation (or creep) implies time dependence. It should be noted, however, that factorial designs assume linearity between levels. A review of the plots in Appendix B suggests that the volumetric creep strain is not linear. If the levels of time are changed, time may lose its relative influence on consolidation. The relatively insignificant influence of temperature has been documented by others [Hansen, 1976; Holcomb and Hannum, 1982].

\subsection{BULK DENSITY RATIO FOR TOTAL CONSOLIDATION}

Table 5-4 gives the relative influence of the four variables on the total consolidation bulk density ratio, $\rho_{f} / \rho_{0}$. Grain size distribution and temperature, to a somewhat lesser degree, are the variables with the greatest influence on $\rho_{f} / \rho_{0}$. This result was seen, at least qualitatively, in figure 4-1. The relatively large influence of grain size distribution is plausible since the uniform-graded distribution starts at a much lower density initially and, therefore, has the potential for greater change in density. This response and the variables that affect it are pertinent to permeability, since they include all consolidation. It is interesting to note the change in the relative importance of the variables when comparing the creep consolidation with the total consolidation. Grain size distribution and temperature are less influential during creep.

\subsection{UNCONFINED COMPRESSIVE STRENGTH}

Table 5-5 gives the relative influence of the four variables on the unconfined compressive strength in terms of the eight statistics. As with creep, 
Table 5-3. Estimate ${ }^{(a)}$ of Variable Effects on the Creep Consolidation Bulk Density Ratio

\begin{tabular}{|c|c|}
\hline Statistic & Estimate \\
\hline Mean & 1.080 \\
\hline $\begin{array}{l}\text { Main Effects } \\
\text { Grain Size Distribution }\end{array}$ & -0.045 \\
\hline Temperature & 0.045 \\
\hline Moisture Content & 0.060 \\
\hline Time & 0.080 \\
\hline $\begin{array}{l}\text { Interactions } \\
\quad \text { Grain Size Distribution } \times \text { Temperature } \\
\quad \text { (Moisture Content } \times \text { Time) }\end{array}$ & 0.020 \\
\hline $\begin{array}{l}\text { Grain Size Distribution } \times \text { Moisture Content } \\
\text { (Temperature } x \text { Time) }\end{array}$ & 0.015 \\
\hline $\begin{array}{l}\text { Grain Size Distribution } \times \text { Time } \\
\text { (Temperature } \times \text { Moisture Content) }\end{array}$ & -0.015 \\
\hline
\end{tabular}

(a) Based on 2 IV 
Table 5-4. Estimate ${ }^{(a)}$ of Variable Effects on the Total Consolidation Bulk Density Ratio

\begin{tabular}{|c|c|}
\hline Statistic & Estimate \\
\hline Mean & 1.2700 \\
\hline $\begin{array}{l}\text { Main Effects } \\
\text { Grain Size Distribution }\end{array}$ & -0.1975 \\
\hline Temperature & 0.1275 \\
\hline Moisture Content & 0.0775 \\
\hline Time & 0.0925 \\
\hline $\begin{array}{l}\text { Interactions } \\
\text { Grain Size Distribution x Temperature } \\
\quad \text { (Moisture Content } \times \text { Time) }\end{array}$ & -0.0225 \\
\hline $\begin{array}{l}\text { Grain Size Distribution } \times \text { Moisture Content } \\
\text { (Temperature } \times \text { Time) }\end{array}$ & 0.0275 \\
\hline $\begin{array}{l}\text { Grain Size Distribution } \times \text { Time } \\
\text { (Temperature } \times \text { Moisture Content) }\end{array}$ & -0.0275 \\
\hline
\end{tabular}

(a) Based on 24V 
Table 5-5. Estimate ${ }^{(a)}$ of Variable Effects on Unconfined Strength

\begin{tabular}{|c|c|}
\hline Statistic & Estimate \\
\hline Mean & $9.0 \mathrm{MPa}$ \\
\hline $\begin{array}{l}\text { Main Effects } \\
\text { Grain Size Distribution }\end{array}$ & 2.1 \\
\hline Temperature & 5.4 \\
\hline Moisture Content & 7.2 \\
\hline Time & 10.2 \\
\hline $\begin{array}{l}\text { Interactions } \\
\text { Grain Size Distribution } \times \text { Temperature } \\
\text { (Moisture Content } \times \text { Time) }\end{array}$ & 4.7 \\
\hline $\begin{array}{l}\text { Grain Size Distribution } \times \text { Moisture Content } \\
\text { (Temperature } \times \text { Time) }\end{array}$ & 4.9 \\
\hline $\begin{array}{l}\text { Grain Size Distribution } \times \text { Time } \\
\text { (Temperature } \times \text { Moisture Content) }\end{array}$ & 7.8 \\
\hline
\end{tabular}

(a) Based on 2 IV 
time and moisture content have the greater influence; however, the two-factor interactions between either grain size distribution and time or temperature and moisture content (from Table 5-2 alias pattern) are also of relatively large importance. In fact, each two-factor interaction is more important or as important as the main effects of grain size distribution and temperature. 
6 CONCLUSIONS

An experiment has been performed on crushed salt from Avery Island, Louisiana, to assess the influence of four variables on the consolidation and unconfined compressive strength of crushed salt. The four variables studied were grain size distribution, temperature, time, and moisture content. A matrix of eight tests was designed using a half-fraction factorial at two levels. The two levels for each variable were grain size distribution, $c_{u}=1$ and 8; temperature, $25^{\circ} \mathrm{C}$ and $100^{\circ} \mathrm{C}$; time, $3.5 \times 10^{3} \mathrm{~s}$ and $950 \times 10^{3} \mathrm{~s}$; and moisture content, dry and wet ( 85 percent relative humidity at $26.5^{\circ} \mathrm{C}$ for 24 hours).

An analysis of the results shows that time, and to a somewhat lesser degree, moisture content have the largest influence on the creep consolidation bulk density ratio. Grain size distribution and temperature have the largest influence on the bulk density ratio during the total consolidation. Time and moisture content have the largest influence on the unconfined compressive strength; and in addition, the two-factor interactions between either grain size distribution and time or temperature and moisture content have a relatively significant effect.

The results obtained from this study should be considered when future experimental crushed salt matrices are designed. The confounded effects between grain size distribution and time and temperature and moisture content should be resolved for the unconfined compressive strength. The confounded effects could be eliminated by either performing the remaining eight runs for a full factorial design or choosing a smaller number of additional runs that when performed resolve the ambiguity. Future studies should retain the four current variables and incorporate new variables to determine their relative significance. Additionally, future experiments should include replication so that data variability can be estimated. Model building can begin when significant variables are identified and should reflect other levels of these variables. 


\section{REFERENCES}

Box, G. E. P, W. G. Hunter, and J. S. Hunter, 1978. Statistics for Experiments, John Wi ley \& Sons, New York, NY.

Hansen, F. D., 1976. Experimental Consolidation of Granulated Rock Salt With Application to Sleeve Buck ling, ORNL-SUB-4269-21, prepared by RE/SPEC Inc. for 0ak Ridge National Laboratory, Union Carbide Corporation - Nuclear Division, Oak Ridge, TN.

Hansen, F. D., and K. D. Mellegard, 1980. Creep of 50-mm Diameter Specimens of Dome Salt From Avery Is land, Louisiana, ONWI-104, prepared by RE/SPEC Inc. for Office of Nuclear Waste Isolation, Battelle Memorial Institute, Columbus, $\mathrm{OH}$.

Holcomb, D. J., and D. W. Hannum, 1982. Consolidation of Crushed Salt Backfill Under Conditions Appropriate to the WIPP Facility, SAND82-0630, prepared for U.S. Department of Energy by Sandia National Laboratories, Albuquerque, NM.

IT Corporation, 1984. Assessment of Crushed Salt Consolidation and Fracture Healing Processes in a Nuclear Waste Repository in Salt, BMI/ONWI-546, prepared for Office of Nuclear Waste Isolation, Battelle Memorial Institute, Columbus, $\mathrm{OH}$.

Shor, A. J., C. F. Baes, Jr., and C. M. Canonico, 1981. Consolidation and Permeability of Salt in Brine, ORNL-5774, prepared for U.S. Department of Energy by 0ak Ridge National Laboratory, Union Carbide Corporation, Oak Ridge, TN.

Stinebaugh, R. E., 1979. Compressibility of Granulated Rock Salt, SAND79-1119, prepared for U.S. Department of Energy by Sandia National Laboratories, A lbuquerque, NM. 


\section{APPENDIX A}

VOLUMETRIC STRAIN-VERSUS-MEAN STRESS

DATA FOR AVERY ISLAND CRUSHED SALT

DURING QUASI-STATIC LOADING 
- 
APPENDIX A

LIST OF FIGURES

Figure

$\underline{\text { Title }}$

Page

A-1. Measured Volumetric Strain-Versus-Mean Stress for Wet

Avery Island Crushed Salt at a Temperature of $100^{\circ} \mathrm{C}$ and

$\mathrm{C}_{\mathrm{u}}$ of $8 \ldots \ldots \ldots \ldots \ldots \ldots \ldots \ldots$

A-2. Measured Volumetric Strain-Versus-Mean Stress for Dry

Avery Island Crushed Salt at a Temperature of $25^{\circ} \mathrm{C}$ and

$\mathrm{C}_{\mathrm{u}}$ of $8 \ldots \ldots \ldots \ldots \ldots \ldots \ldots \ldots \ldots \ldots$

A-3. Measured Volumetric Strain-Versus-Mean Stress for Dry

Avery Island Crushed Salt at a Temperature of $100^{\circ} \mathrm{C}$ and

$\mathrm{C}_{\mathrm{u}}$ of $8 \ldots \ldots \ldots \ldots \ldots \ldots \ldots \ldots \ldots$

A-4. Measured Volumetric Strain-Versus-Mean Stress for Wet

Avery Island Crushed Salt at a Temperature of $25^{\circ} \mathrm{C}$ and

$\mathrm{C}_{\mathrm{u}}$ of $8 \ldots \ldots \ldots \ldots \ldots \ldots . . \ldots \ldots$

A-5. Measured Volumetric Strain-Versus-Mean Stress for Dry

Avery Island Crushed Salt at a Temperature of $100^{\circ} \mathrm{C}$ and

$\mathrm{c}_{\mathrm{u}}$ of $\ldots \ldots \ldots \ldots \ldots \ldots \ldots \ldots \ldots$

A-6. Measured Volumetric Strain-Versus-Mean Stress for Wet

Avery Is land Crushed Salt at a Temperature of $25^{\circ} \mathrm{C}$ and

$\mathrm{c}_{\mathrm{u}}$ of $\ldots \ldots \ldots \ldots \ldots \ldots \ldots$

A-7. Measured Volumetric Strain-Versus-Mean Stress for Wet

Avery Island Crushed Salt at a Temperature of $100^{\circ} \mathrm{C}$ and

$c_{u}$ of $\ldots \ldots \ldots \ldots \ldots \ldots . . . \ldots$

A-8. Measured Volumetric Strain-Versus-Mean Stress for Dry

Avery Island Crushed Salt at a Temperature of $25^{\circ} \mathrm{C}$ and

$c_{u}$ of $1 \ldots \ldots \ldots \ldots \ldots$ 
$R-001-84-388$

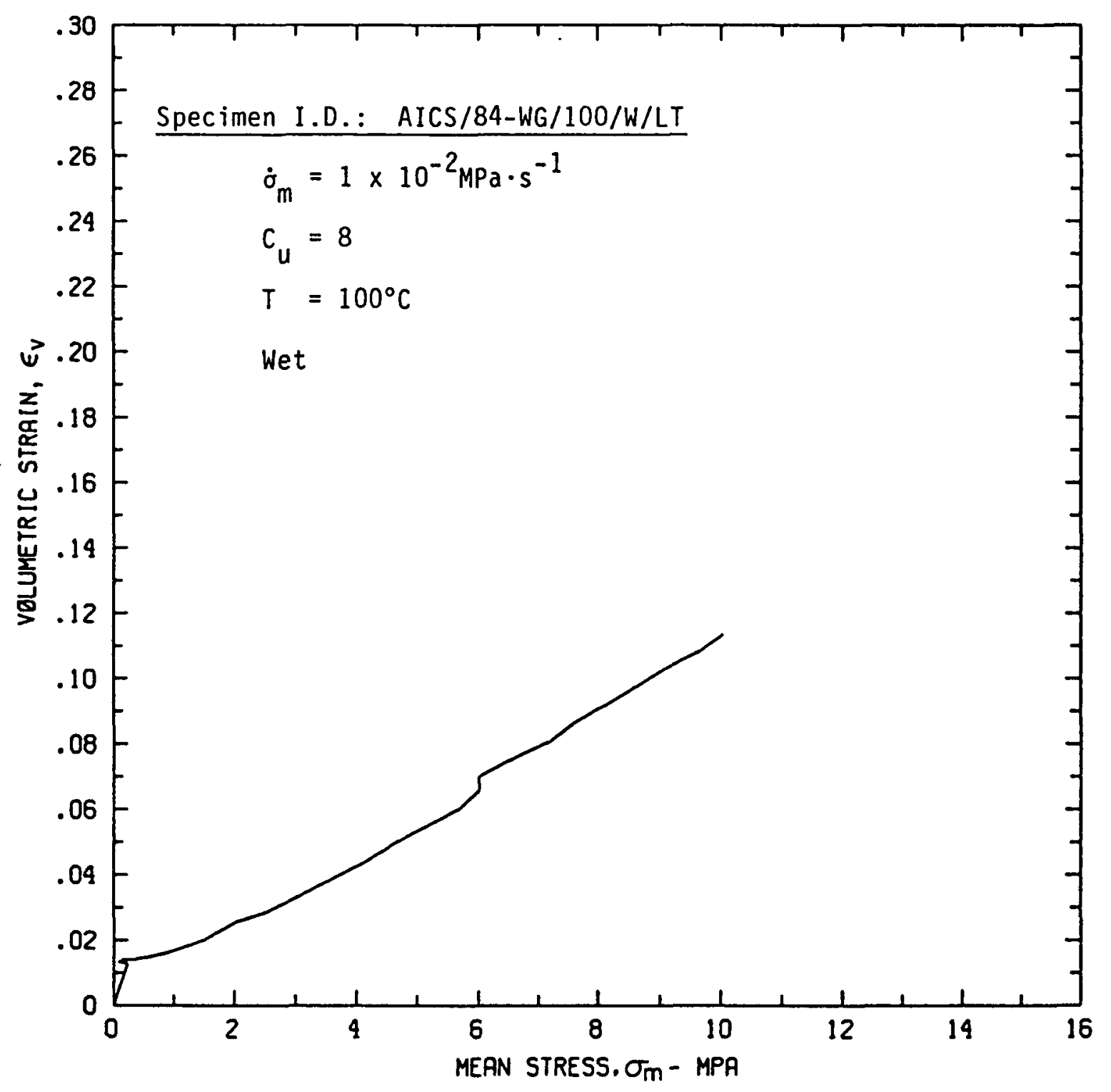

Figure A-1. Measured Volumetric Strain-Versus-Mean Stress for Wet Avery Island Crushed Salt at a Temperature of $100^{\circ} \mathrm{C}$ and $c_{u}$ of 8 
$R-001-84-389$

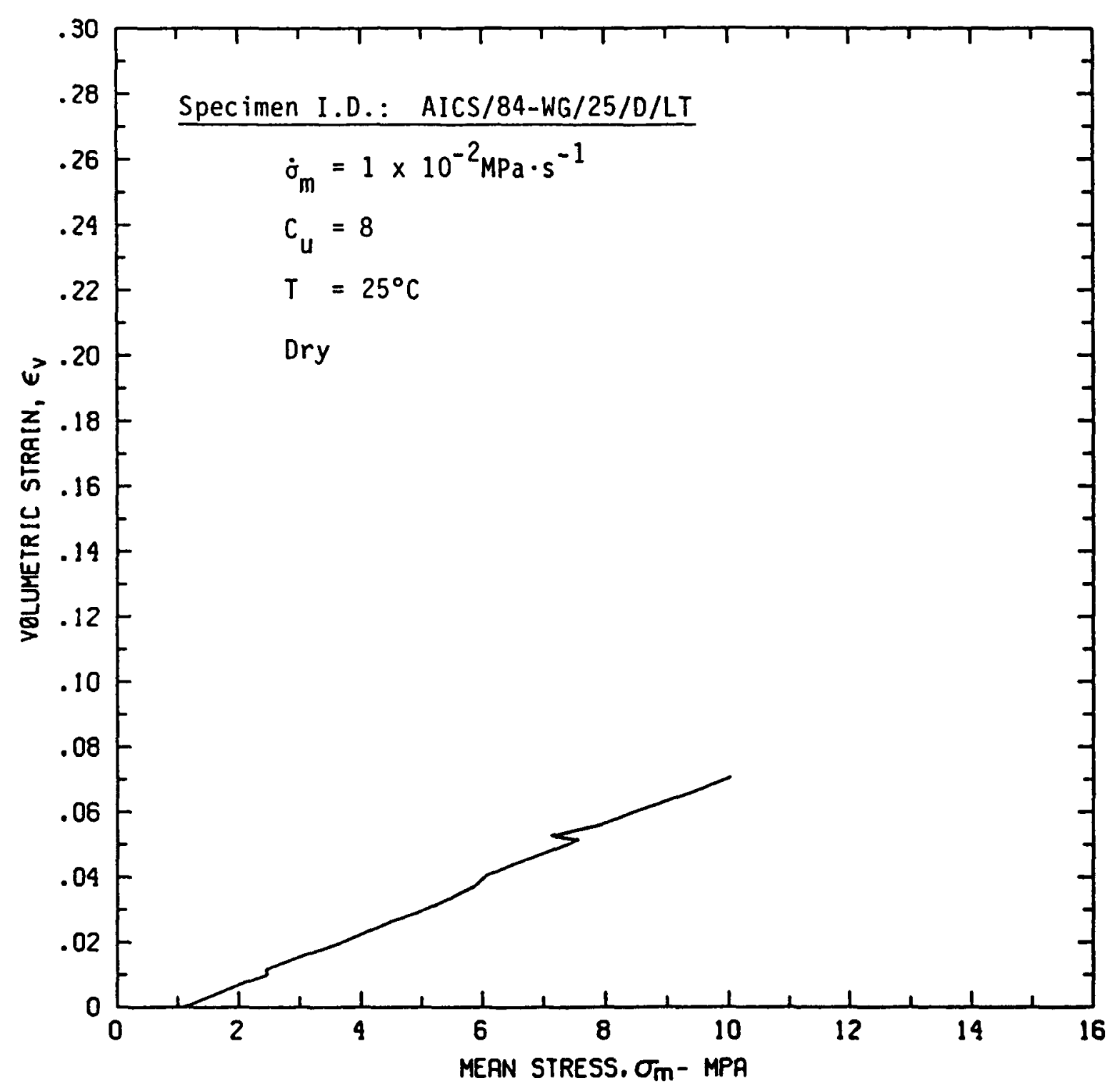

Figure A-2. Measured Volumetric Strain-Versus-Mean Stress for Dry Avery Island Crushed Salt at a Temperature of $25^{\circ} \mathrm{C}$ and $\mathrm{C}_{\mathrm{u}}$ of 8 
$R-001-84-392$

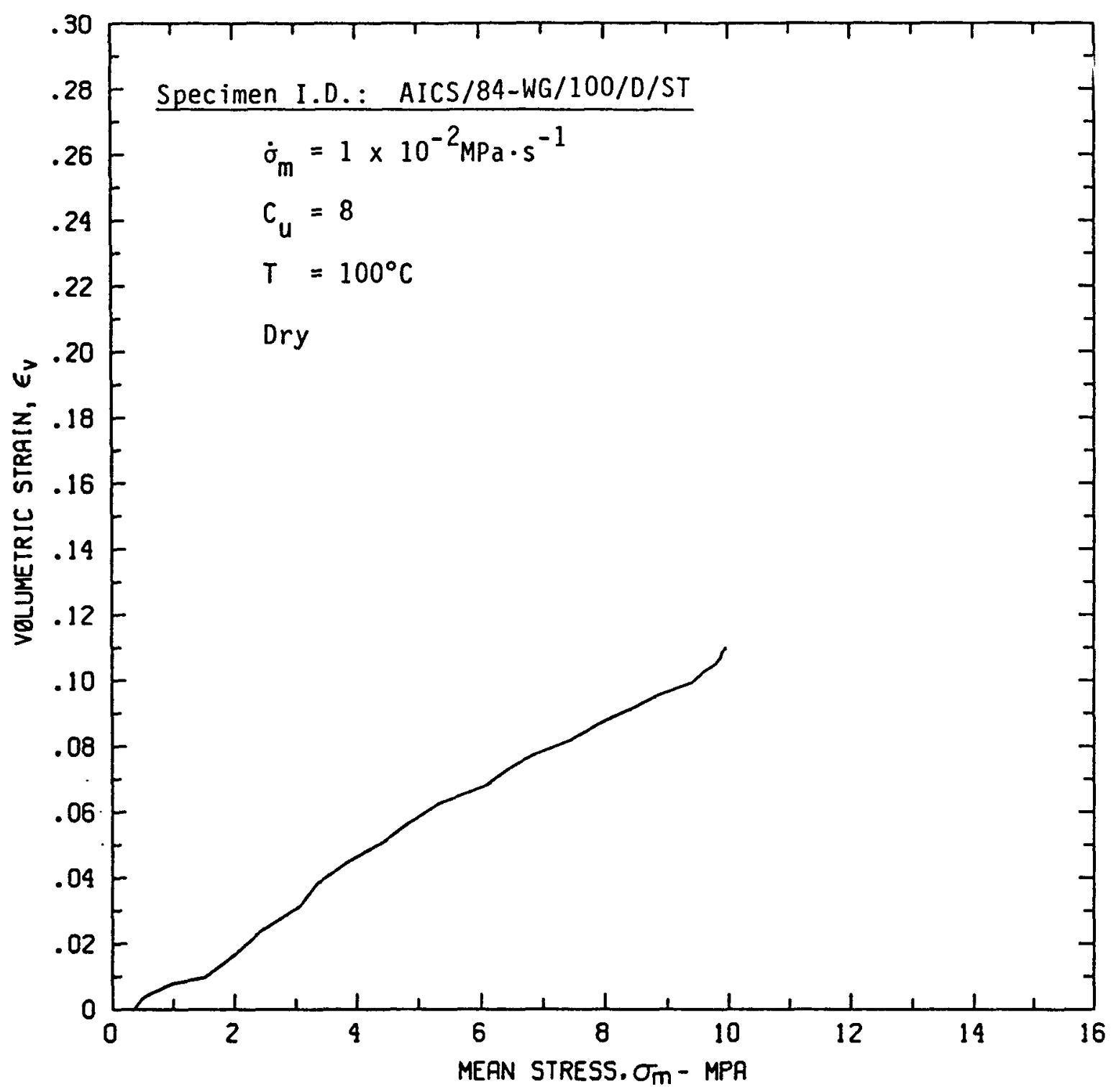

Figure A-3. Measured Volumetric Strain-Versus-Mean Stress for Dry Avery Island Crushed Salt at a Temperature of $100^{\circ} \mathrm{C}$ and $\mathrm{C}_{\mathrm{u}}$ of 8 
$R-001-84-391$

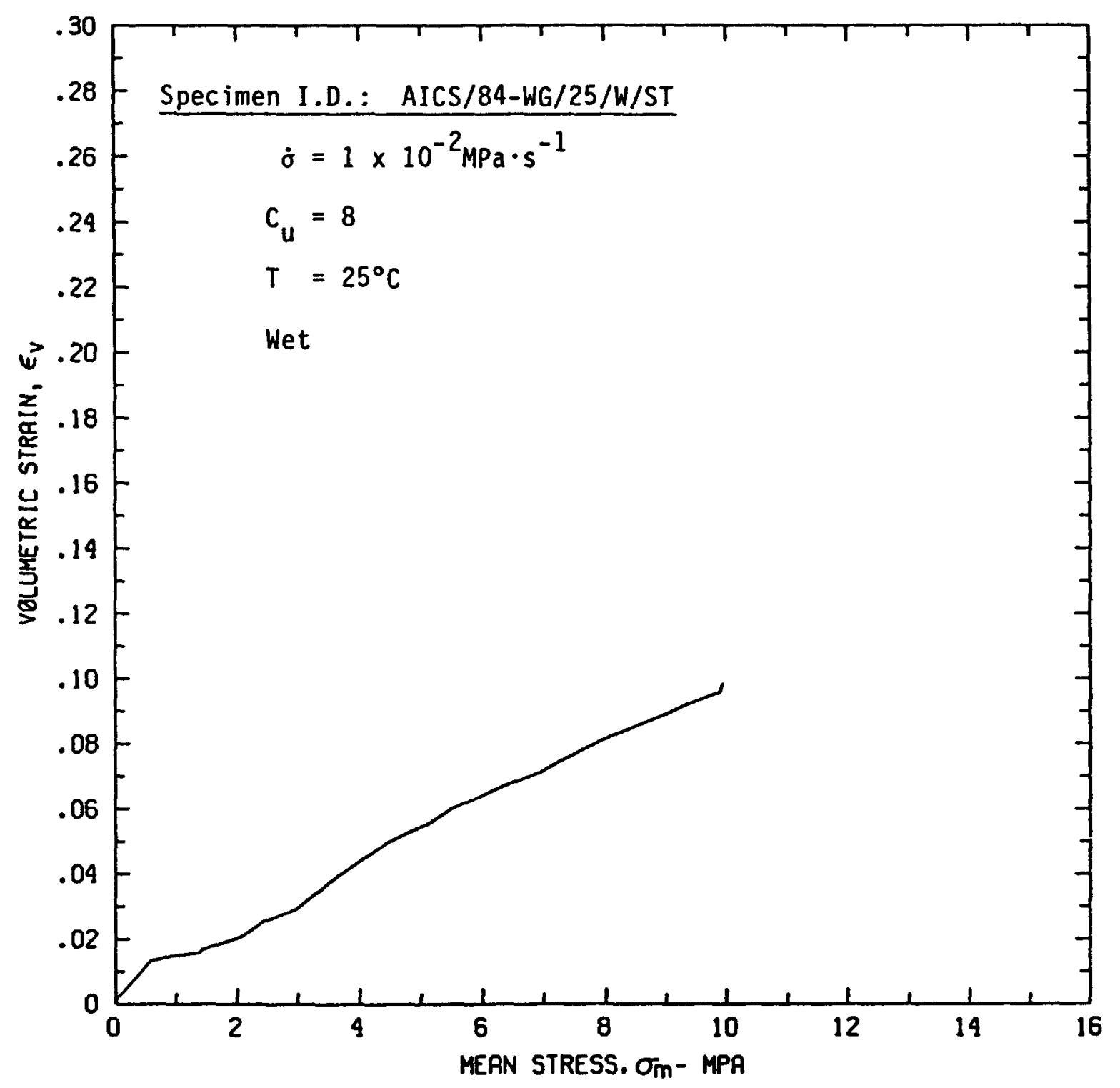

Figure A-4. Measured Volumetric Strain-Versus-Mean Stress for Wet Avery Island Crushed Salt at a Temperature of $25^{\circ} \mathrm{C}$ and $\mathrm{C}_{\mathrm{u}}$ of 8 
R-00I-84-390

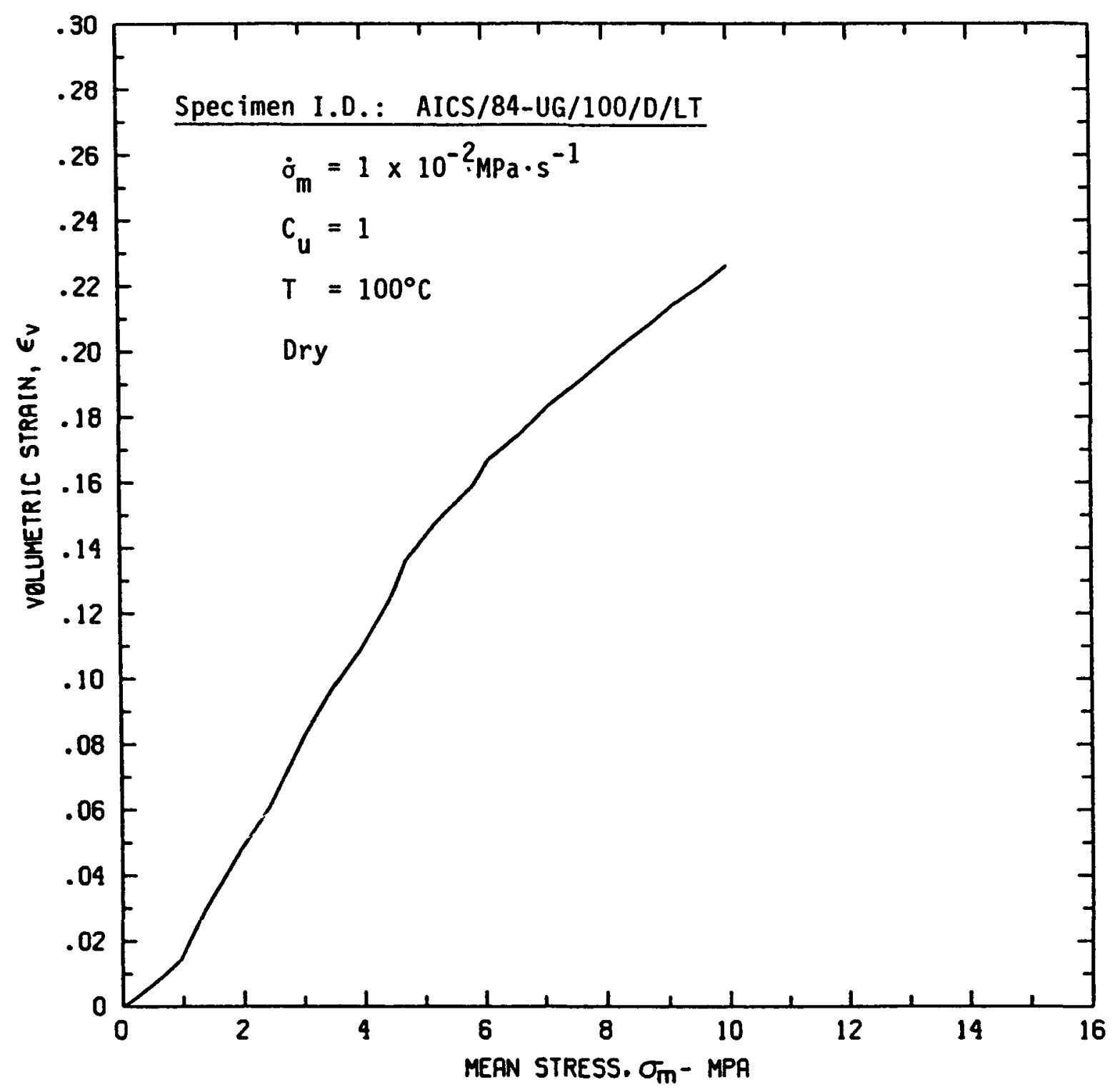

Figure A-5. Measured Volumetric Strain-Versus-Mean Stress for Dry Avery Island Crushed Salt at a Temperature of $100^{\circ} \mathrm{C}$ and $C_{u}$ of 1 


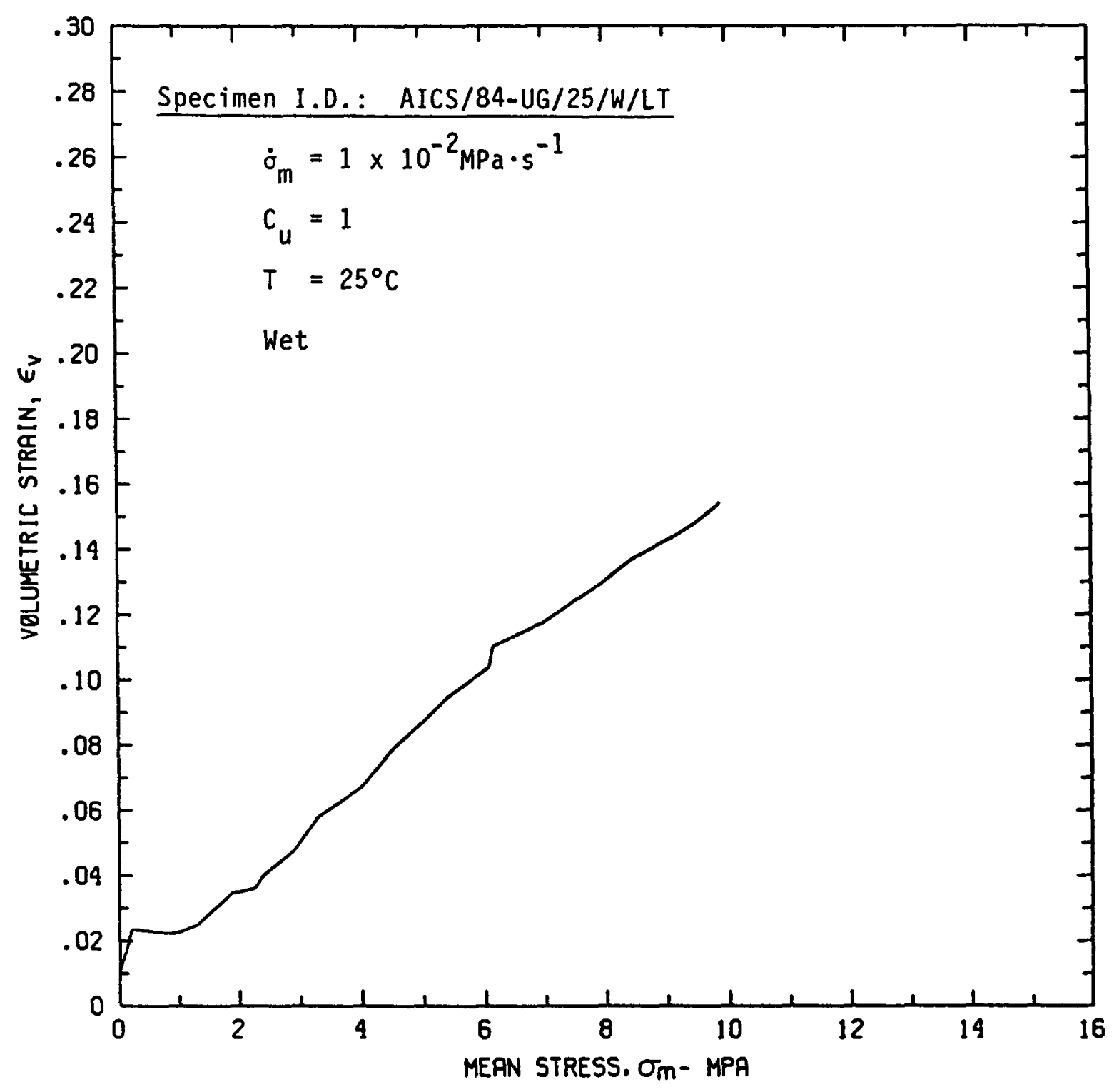

Figure A-6. Measured Volumetric Strain-Versus-Mean Stress for Wet Avery Island Crushed Salt at a Temperature of $25^{\circ} \mathrm{C}$ and $C_{u}$ of 1 
R-001-84-394

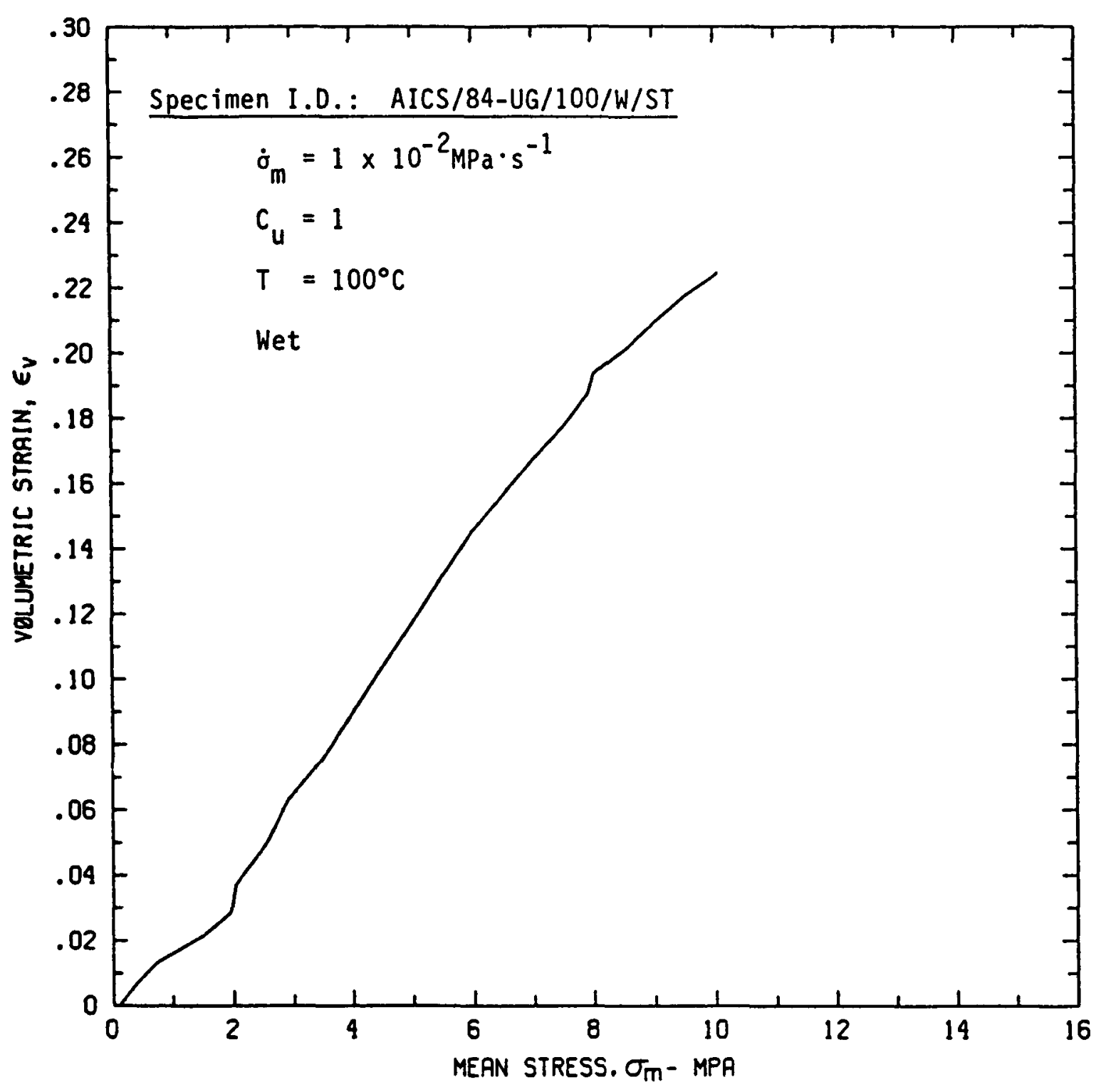

Figure A-7. Measured Volumetric Strain-Versus-Mean Stress for Wet Avery Island Crushed Salt at a Temperature of $100^{\circ} \mathrm{C}$ and $C_{u}$ of 1 


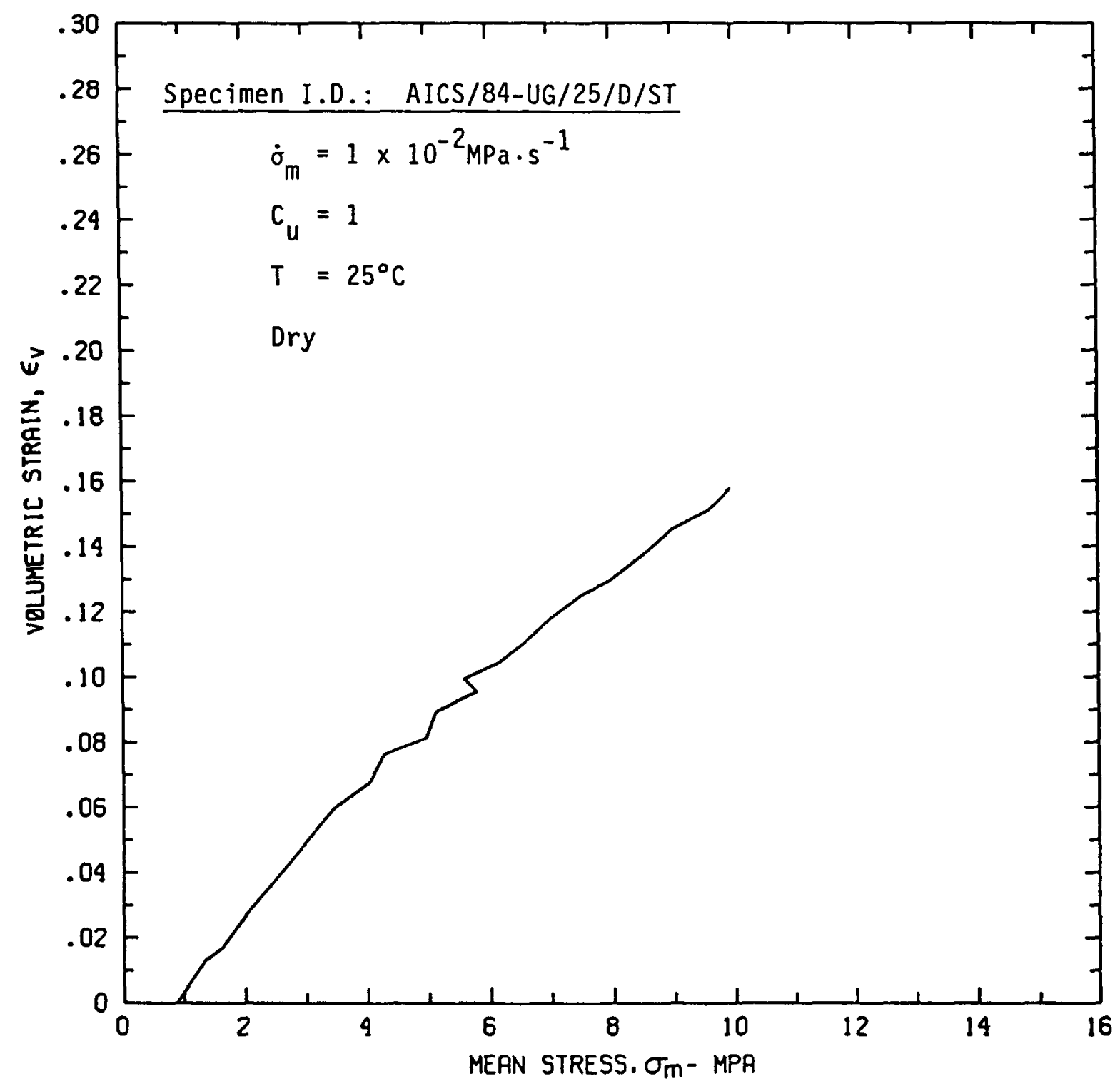

Figure A-8. Measured Volumetric Strain-Versus-Mean Stress for Dry Avery Island Crushed Salt at a Temperature of $25^{\circ} \mathrm{C}$ and $\mathrm{C}_{u}$ of 1 
APPENDIX B

VOLUMETRIC STRAIN-VERSUS-TIME DATA

FOR AVERY ISLAND CRUSHED SALT

DURING CONSOLIDATION (CREEP) 
APPENDIX B

LIST OF FIGURES

Figure

Title

Page

B-1. Measured Volumetric Creep Strain for Wet Avery Island Crushed Salt at a Temperature of $100^{\circ} \mathrm{C}$ and $\mathrm{C}_{u}$ of $8 \ldots . .$.

B-2. Measured Volumetric Creep Strain for Dry Avery IsI and Crushed Salt at a Temperature of $25^{\circ} \mathrm{C}$ and $\mathrm{C}_{u}$ of $8 \ldots . .$.

B-3. Measured Volumetric Creep Strain for Dry Avery Island Crushed Salt at a Temperature of $100^{\circ} \mathrm{C}$ and $C_{u}$ of $8 \ldots \ldots$

B-4. Measured Volumetric Creep Strain for Wet Avery Island Crushed Salt at a Temperature of $25^{\circ} \mathrm{C}$ and $\mathrm{C}_{u}$ of $8 \ldots . .$.

B-5. Measured Volumetric Creep Strain for Dry Avery Island Crushed Salt at a Temperature of $100^{\circ} \mathrm{C}$ and $C_{u}$ of $1 \ldots . .$.

B-6. Measured Volumetric Creep Strain for Wet Avery Island Crushed Salt at a Temperature of $25^{\circ} \mathrm{C}$ and $C_{u}$ of $1 \ldots 60$

B-7. Measured Volumetric Creep Strain for Wet Avery Island Crushed Salt at a Temperature of $100^{\circ} \mathrm{C}$ and $C_{u}$ of $1 \ldots 61$

B-8. Measured Volumetric Creep Strain for Dry Avery Island Crushed Salt at a Temperature of $25^{\circ} \mathrm{C}$ and $C_{u}$ of $1 \ldots 62$ 
$R-001-84-437$

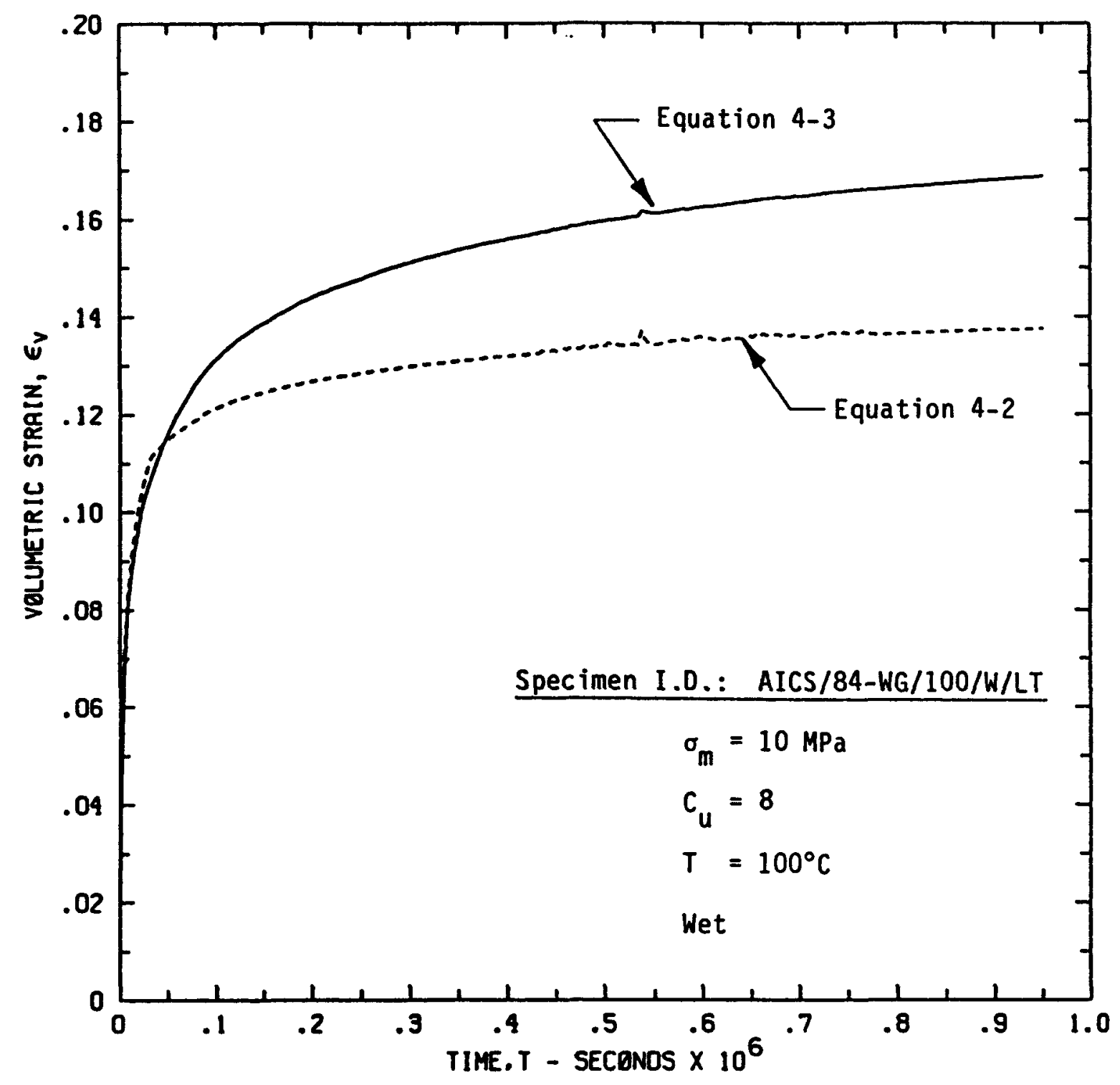

Figure B-1. Measured Volumetric Creep Strain for Wet Avery Island Crushed Salt at a Temperature of $100^{\circ} \mathrm{C}$ and $C_{u}$ of 8 


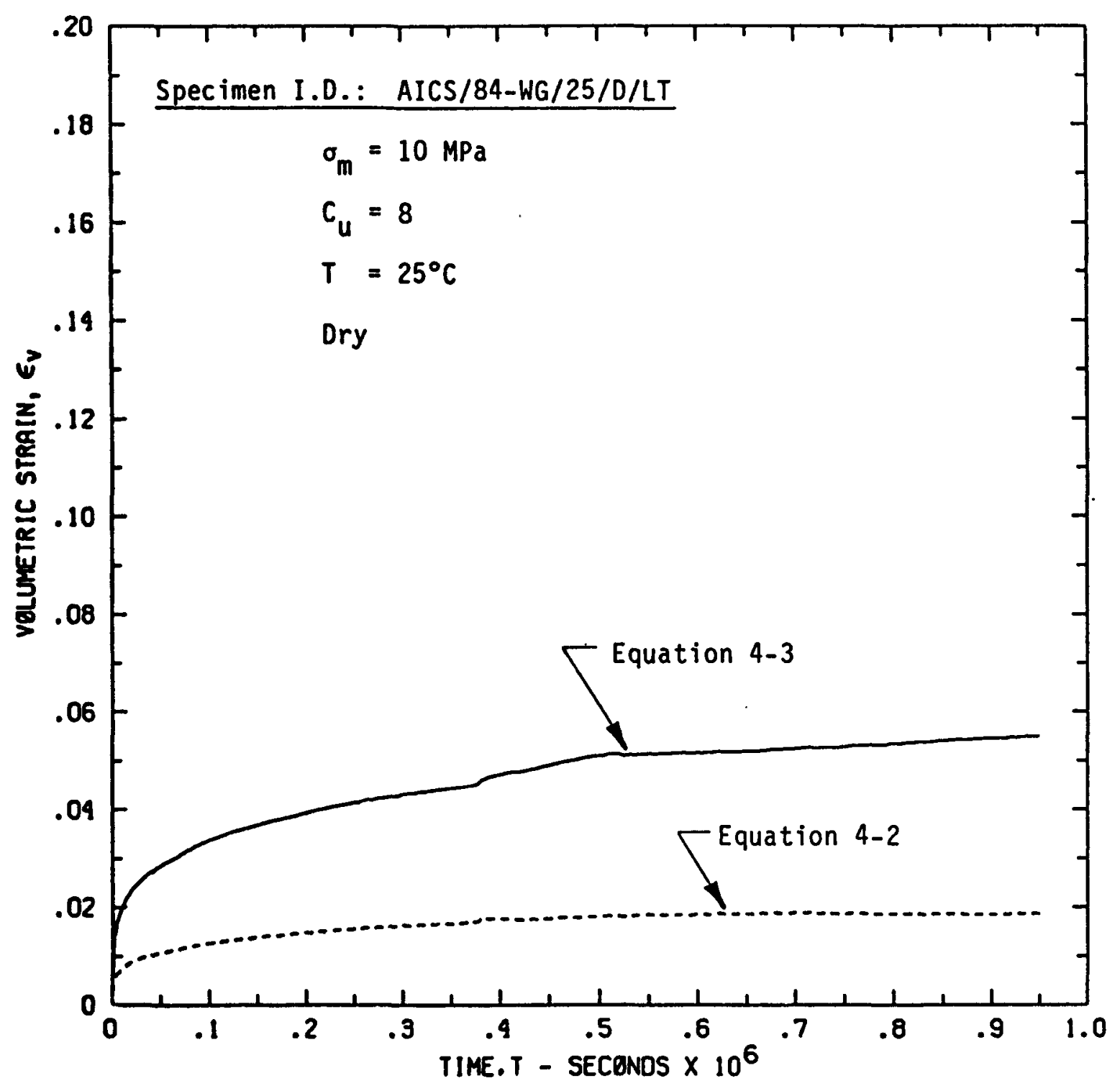

Figure 8-2. Measured Volumetric Creep Strain for Dry Avery Is Iand Crushed Salt at a Temperature of $25^{\circ} \mathrm{C}$ and $\mathrm{C}_{u}$ of 8 
$R-001-84-397$

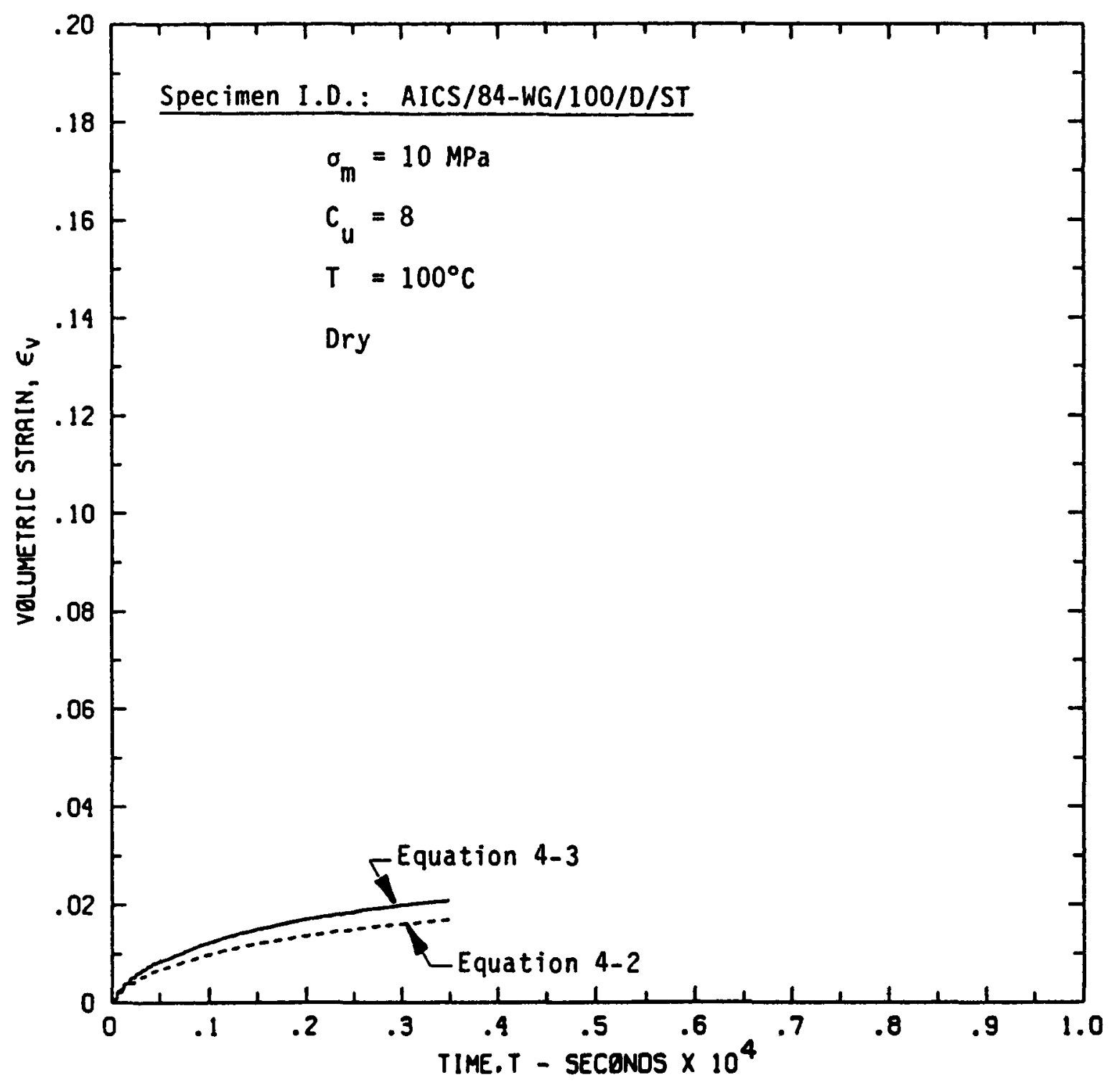

Figure B-3. Measured Volumetric Creep Strain for Dry Avery Island Crushed Salt at a Temperature of $100^{\circ} \mathrm{C}$ and $C_{u}$ of 8 
$R-001-84-398$

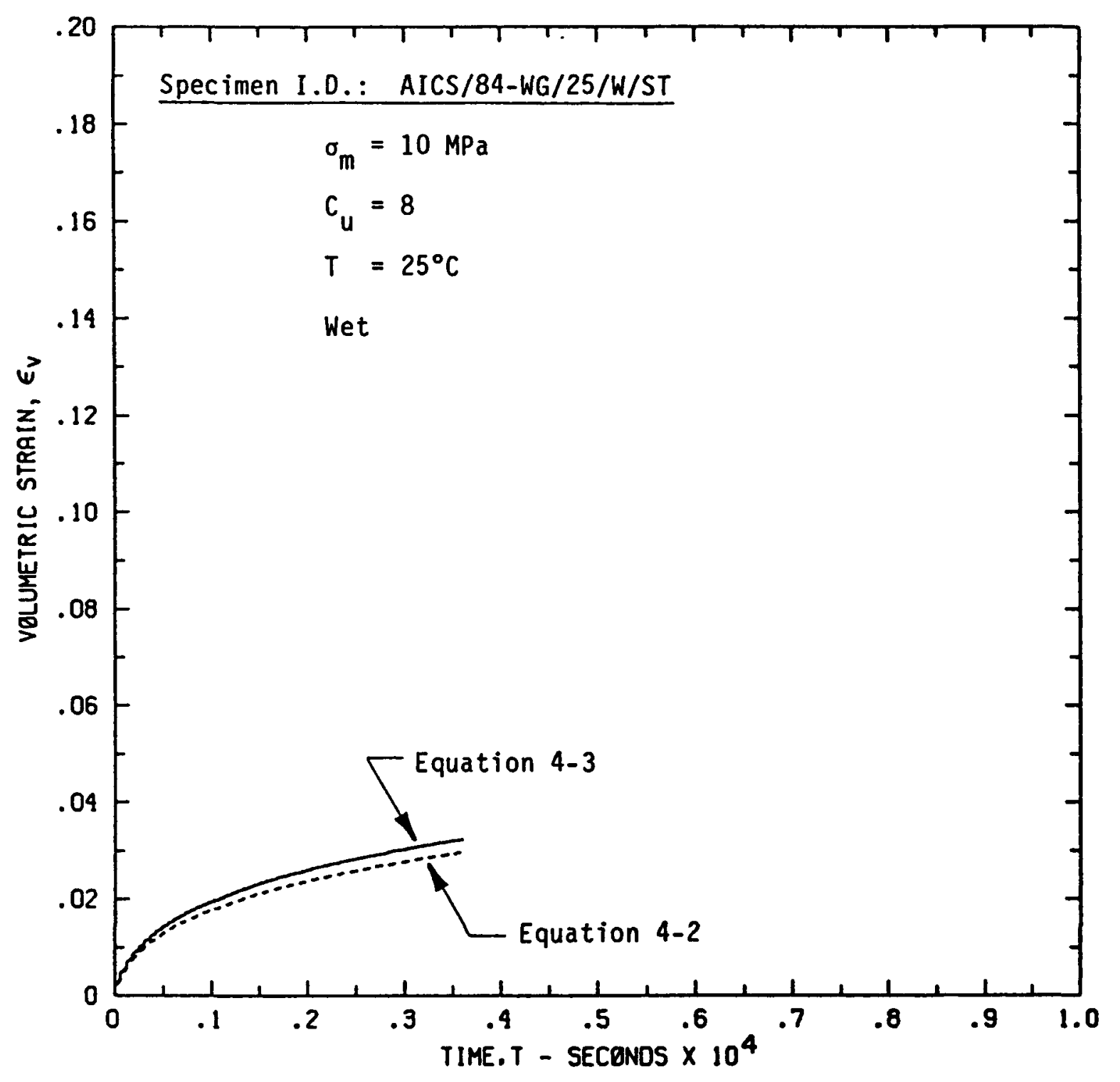

Figure B-4. Measured Volumetric Creep Strain for Wet Avery Island Crushed Salt at a Temperature of $25^{\circ} \mathrm{C}$ and $C_{u}$ of 8 
R-001-84-399

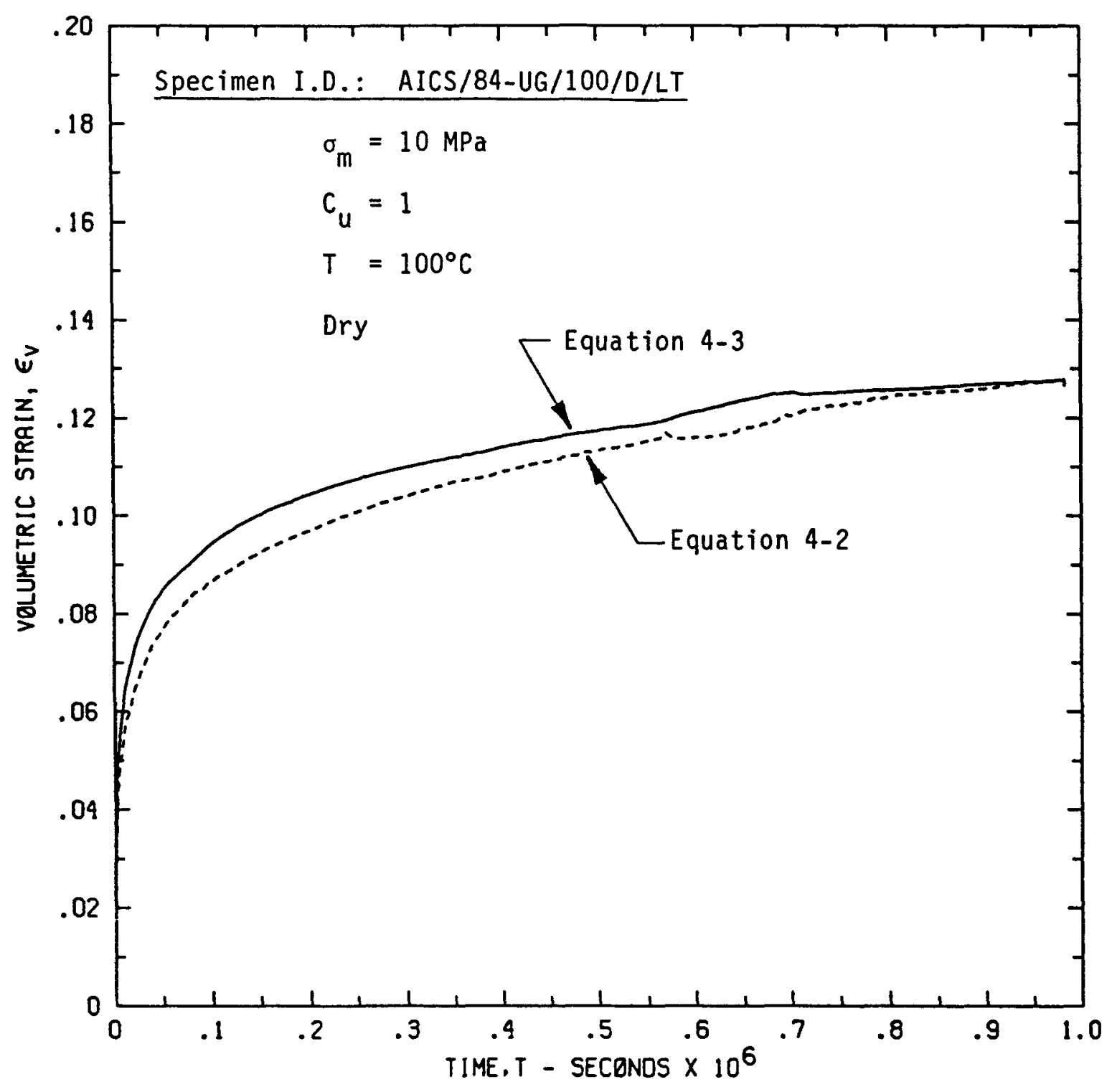

Figure B-5. Measured Volumetric Creep Strain for Dry Avery Island Crushed Salt at a Temperature of $100^{\circ} \mathrm{C}$ and $\mathrm{Cu}$ of 1 


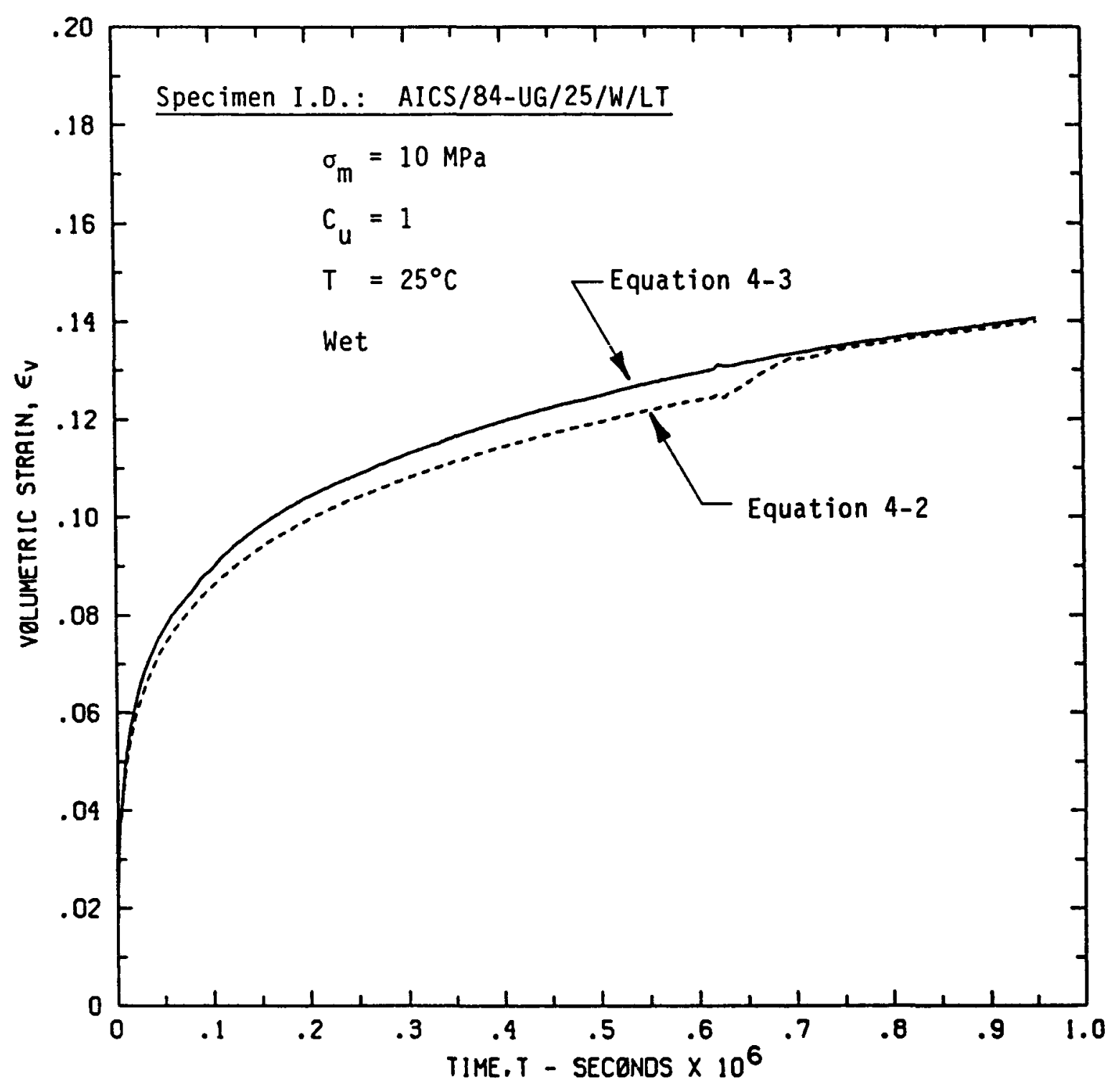

Figure B-6. Measured Volumetric Creep Strain for Wet Avery Island Crushed Salt at a Temperature of $25^{\circ} \mathrm{C}$ and $\mathrm{C}_{u}$ of 1 


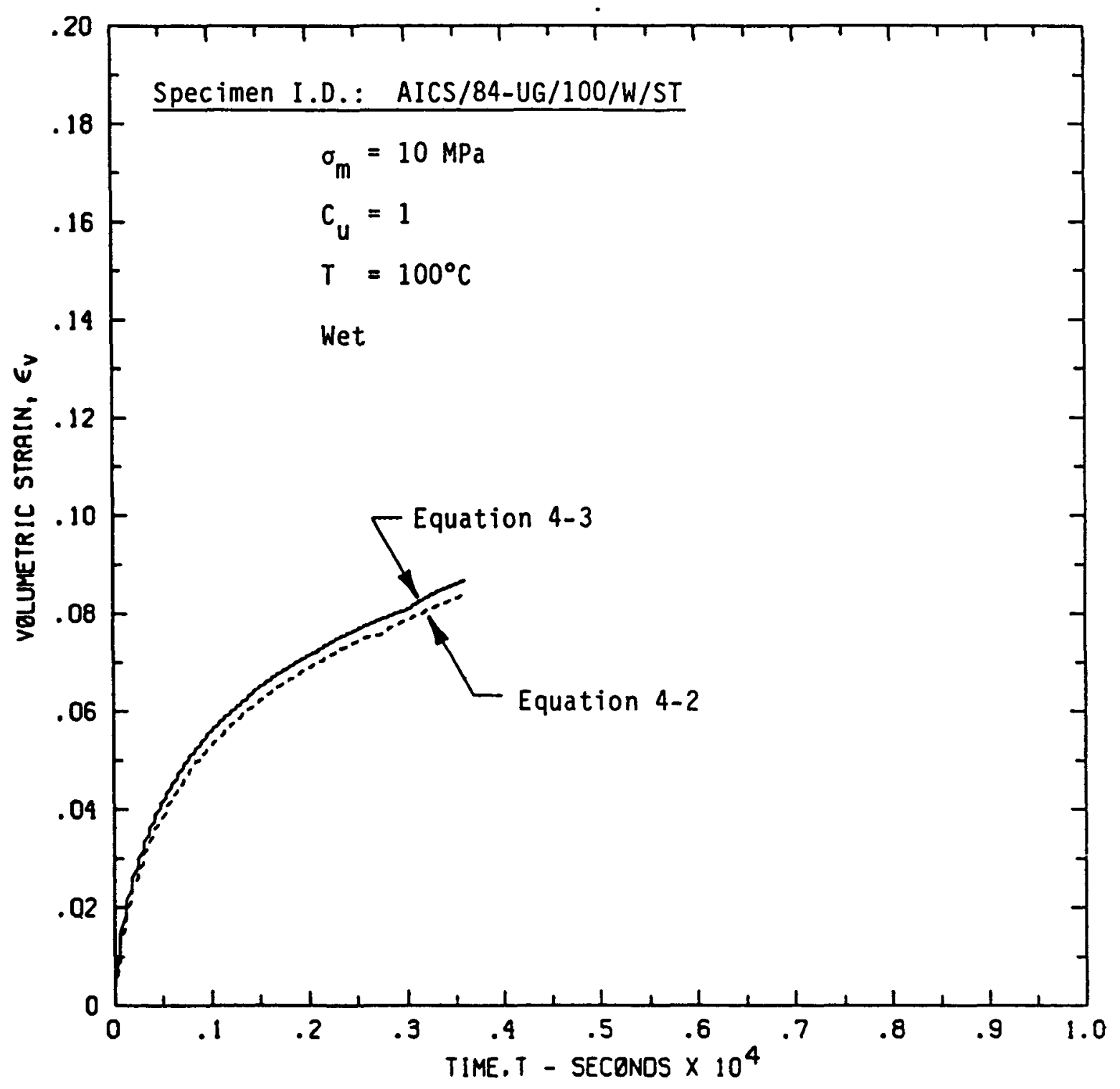

Figure B-7. Measured Volumetric Creep Strain for Wet Avery Island Crushed Salt at a Temperature of $100^{\circ} \mathrm{C}$ and $C_{u}$ of 1 


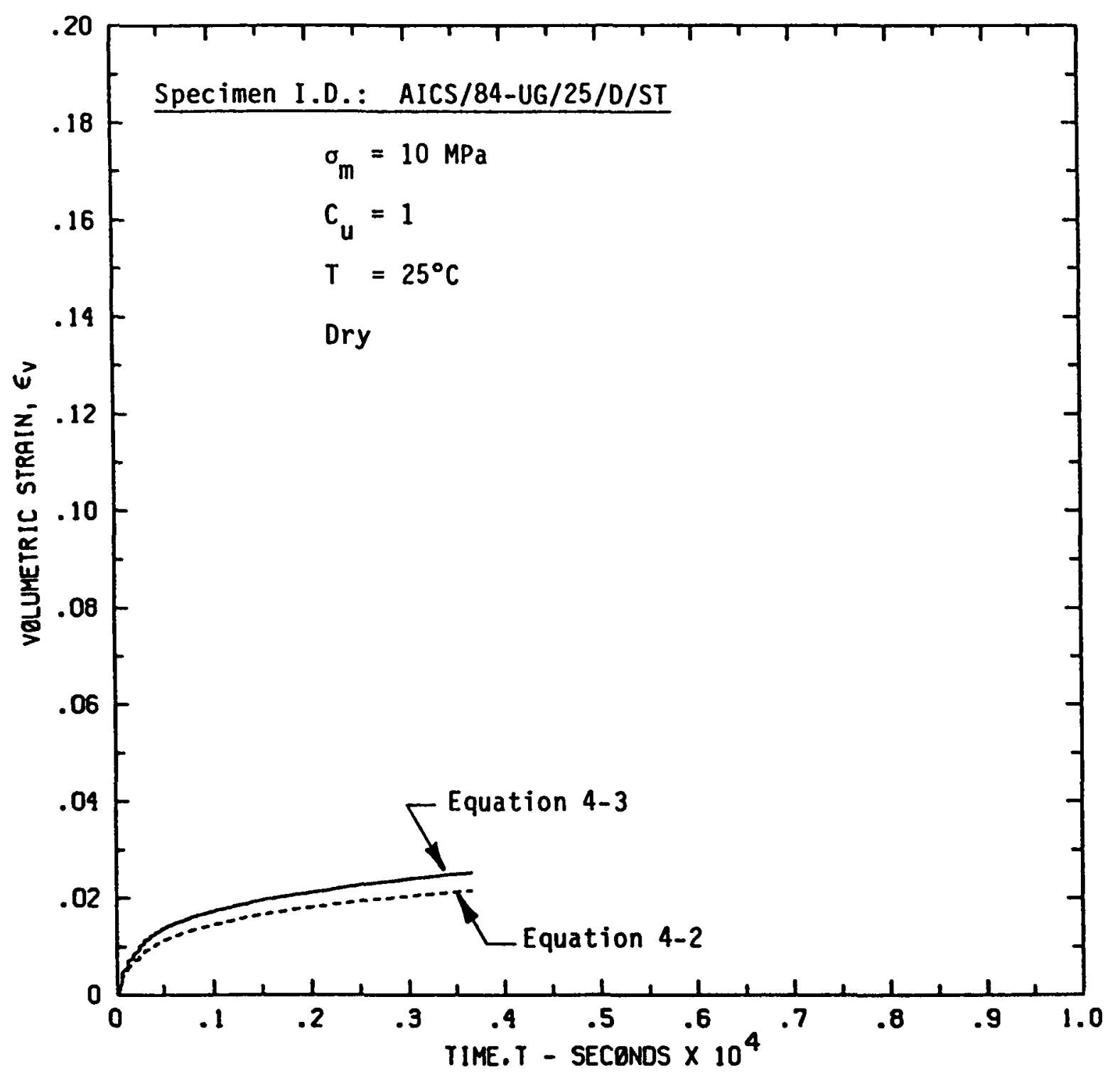

Figure B-8. Measured Volumetric Creep Strain for Ory Avery Island Crushed Salt at a Temperature of $25^{\circ} \mathrm{C}$ and $C_{u}$ of 1 . 


\section{DISTRIBUTION LIST}

ACRES INTERNATIONAL CORP STEWART N. THOMPSON ALABAMA STATE GEOLOGICAL SURVEY THORNTON L. NEATHERY

AMARILLO PUBLIC LIBRARY

AMERICAN ROCK WRITING RESEARCH JOHN NOXON

APPLIED RESEARCH ASSOCIATES STEVEN WOOLFOLK

ARGONNE NATIONAL LABORATORY DORLAND E. EDGAR DOUGLAS F. HAMBLEY WYMAN HARRISON MARTIN I. STEINDLER YU CHIEN YUAN

ARIZONA NUCLEAR POWER PROIECT HENRY W. RILEY, JR.

ARIZONA STATE UNIVERSITY PAUL KNAUTH

ARTHUR D. LITTLE INC CHARLES R. HADLOCK

ATOMIC ENERGY CONSULTANTS DONALD G. ANDERSON

ATOMIC ENERGY CONTROL. BOARD-CANADA KEN SHULTZ

ATOMIC ENERGY OF CANADA LTD T. CHAN SIEGRUN MEYER

ATOMIC ENERGY RESEARCH ESTABLISHMENTUNITED KINGDOM D. P. HODGKINSON

BATTELLE MEMORIAL INSTITUTE JAMES DUGUID JOHN T. MCGINNIS JEFFREY L. MEANS CARL SPILKER

BCM CONVERSE INC. ROBERT J. MANUEL

BECHTEL NATIONAL INC BEVERLY S. AUSMUS LESLIE J. JARDINE T. R. MONGAN

BENDIX FIELD ENGINEERING CORP LARRY M. FUKUI CHARIES A. JONES ANTHONY ZAIKOWSKI

BERKELEY GEOSCIENCES/HYDROTECHNIQUE ASSOCIATES BRIAN KANEHIRO

BOWDOIN COLLEGE EDWARD P. LAINE

BRENK SYSTEMPLANUNG-W. GERMANY H. D. BRENK

BRITISH GEOLOGICAL SURVEY DAVID MICHAEL MCCANN

BROOKHAVEN NATIONAL LABORATORY

M. S. DAVIS

HELEN TODOSOW (2)

BROOME COMMUNITY COLLEGE BRUCE OLDFIELD

BROWN UNIVERSITY MICHELE BURKE

BUNDESANSTALI FUR GEOWISSENSCHAFTEN UND ROHSTOFFE- $W$. GERMANY MICHAEL LANGER HELMUT VENZLAFF

BUREAU DE RECHERCHES GEOLOGIQUES ET MINIERES-FRANCE

BERNARD FEUGA PIERRE F. PEAUDECERF
CALIFORNIA DEPT OF CONSERVATION PERRY AMIMITO

CANVIRO CONSULTANTS DOUG METCALFE

CAPITAL UNIVERSITY VICTOR M. SHOWALTER

CAYUGA LAKE CONSERVATION ASSOCIATION INC

D. S. KIEFER

CELSIUS ENERGY COMPANY NICK THOMAIDIS

CENTER FOR ENVIRONMENTAL HEALTH CAMERON MCDONALD VOWELL

CENTER FOR INTERDISCIPLINARY STUDIES DAVID M. ARMSTRONC

CER CORP ELLA JACKSON

CHEVRON OIL FIELD RESEARCH COMPANY BJORN PAULSSON

CITIZENS AGAINST NUCLEAR DISPOSAL INC STANLEY D. FLINT

CLARK UNIVERSITY JEANNE X. KASPERSON

CLIFFS ENGINEERING INC GARY D. AHO

COLBY COLLEGE BRUCE F. RUEGER

COLORADO GEOLOGIC INC MIKE E. BRAZIE

COLORADO GEOLOGICAL SURVEY JOHN W. ROLD

COLORADO SCHOOL OF MINES W. HUSTRULID

COLUMBIA UNIVERSITY M. ASHRAF MAHTAB

CORNELL UNIVERSITY ARTHUR L. BLOOM DUANE CHAPMAN FRED H. KULHAWY ROBERT POHL

COUNCIL OF ENERGY RESOURCE TRIBES WYATT M. ROGERS, JR.

DAMES \& MOORE RON KEAR ROBERT W. KUPP CHARLES R. LEWIS

DANIEL B. STEPHENS AND ASSOCIATES ROBERT G. KNOWLTON, JR.

DEAF SMITH COUNTY LIBRARY

DEPARTMENT OF THE NAVY GENNARO MELLIS

DEPT OF ENERGY, MINES AND RESOURCES CANADA

A. S. JUDGE

DESERET NEWS JOSEPH BAUMAN

DEUTSCHE GESELLSCHAFT ZUM BAU UND

BETRIEB VON ENDLAGERN GERNOT GRUBLER

DISPOSAL SAFETY INC BENJAMIN ROSS

DUNN GEOSCIENCE CORP WILLIAM E. CUTCLIFFE

DYNATECH RESEARCH/DEVELOPMENT COMPANY STEPHEN E. SMITH

E.I. DU PONT DE NEMOURS \& CO A. B. MILLER

EARTH RESOURCE ASSOCIATES INC SERGE GONZALES
EARTH SCIENCE AND ENGINEERING INC LOU BLANCK

EARTH SCIENCES CONSULTANTS INC HARRY L. CROUSE

EBASCO SERVICES INC KATHLEEN E. L. HOWE GARRY MAURATH

ECOLOGY \& ENVIRONMENT INC MICHAEL BENNER

EG \& G IDAHO INC BRENT F. RUSSELL

ELEKTRIZITAETS-GES. LAUFENBURG SWITZERLAND H. N. PATAK

ELSAM-DENMARK ARNE PEDERSEN

ENERGY FUELS NUCLEAR INC DON M. PILLMORE

ENERGY RESEARCH GROUP INC MARC GOLDSMITH

ENGINEERING ANALYSIS INC WILLIAM MULLEN

ENGINEERS INTERNATIONAL INC ROBERT A. CUMMINGS LIBRARY MADAN M. SINGH

ENVIRONMENTAL DEFENSE FUND JAMES B. MARTIN

ENVIRONMENTAL POLICY INSTITUTE DAVID M. BERRICK

ENVIROSPHERE COMPANY ROGER G. ANDERSON

EXXON COMPANY MICHAEL FARRELL

F.J. SCHLUMBERGER PETER ALEXANDER

FENIX \& SCISSON INC CHARLENE U. SPARKMAN

FERRIS STATE COLLEG MICHAEL E. ELLS

FINNISH CENTRE FOR RADIATION AND NUCLEAR SAFETY KAI JAKOBSSON

FLORIDA INSTITUTE OF TECHNOLOGY IOSEPH A. ANGELO, IR.

FLORIDA STATE UNIVERSITY JOSEPH F. DONOGHUE

FLUOR IECHNOLOGY INC WILLIAM LEE (F2X) THOMAS O. MALLONEE, JR (F2X)

FUTURE RESOURCES ASSOCIATES INC ROBERT I. BUDNITZ

GA TECHNOLOGIES INC MICHAEL STAMATELATOS

GARTNER LEE ASSOCIATES LTD-CANADA ROBERT E. J. LEECH

GEOLOGICAL SURVEY OF CANADA JEFFREY HUME LIBRARY

GEOLOGICAL SURVEY OF NORWAY SICURD HUSEBY

GEOMIN INC J. A. MACHADO

GEORGIA INSTITUTE OF TECHNOLOGY ALFRED SCHNEIDER CHARLES E. WEAVER

GEOSTOCK-FRANCE CATHERINE GOUGNAUD

GEOSYSTEMS RESEARCH INC RANDY L. BASSETT 
GEOTHERMAL ENERGY INSTITUTE DONALD F. X. FINN

GEOTRANS INC JAMES MERCER

GOLDER ASSOCIATES MELISSA MATSON J. W. VOSS

GOLDER ASSOCIATES-CANADA CLEMENT M. K. YUEN

GRAND COUNTY PUBLIC LIBRARY

GRIMCO DONALD H. KUPFER

GRUPPE OKOLOGIE (GOK) JURGEN KREUSCH

GUSTAVSON ASSOCIATES RICHARD M. WINAR

H-TECH LABORATORIES INC BRUCE HARTENBAUM

HANFORD OVERSIGHT COMMITTEE LARRY CALDWELL

HART-CROWSER AND ASSOCIATES MICHAEL BAILEY

HARVARD UNIVERSITY CHARLES W. BURNHAM DADE W. MOELLER RAYMOND SIEVER

HARZA ENGINEERING COMPANY PETER CONROY

HEREFORD NUCLEAR WASTE INFORMATION OFFICE MARTHA SHIRE

HIGH LEVEL NUCLEAR WASTE OFFICE PATRICK D. SPURGIN (5)

HIGH PLAINS WATER DISTRICT DON MCREYNOLDS A. WAYNE WYATT

HITACHI WORKS, HITACHI LTD MAKOTO KIKUCHI

HOUGH-NORWOOD HEALTH CARE CENTER CEORGE H. BROWN, M.D.

HUMBOLDT STATE UNIVERSITY JOHN LONGSHORE

ILLINOIS DEPT OF NUCLEAR SAFETY IOHN COOPER

ILLINOIS STATE GEOLOGICAL SURVEY KEROS CARTWRIGHT MORRIS W. LEIGHTON E. DONALD MCKAY, III

INDIANA GEOLOGICAL SURVEY MAURICE BIGGS

INDIANA UNIVERSITY CHARLES J. VITALIANO

INSTITUT FUR TIEFLAGERUNG-W. GERMANY WERNT BREWITZ H. GIES E. R. SOLTER

INSTITUTE OF GEOLOGICAL

SCIENCES-ENGLAND STEPHEN THOMAS HORSEMAN

INSTITUTE OF PLASMA PHYSICS H. AMANO

INTER/FACE ASSOCIATES INC RON GINGERICH

INTERA TECHNOLOGIES INC JAMES E. CAMPBELL F. J. PEARSON, JR. JOHN F. PICKENS MARK REEVES

INTERNATIONAL ENGINEERING COMPANY INC MAX ZASLAWSKY

INTERNATIONAL GROUND WATER MODELING CENTER

PAUL K. M. VAN DER HEIJDE
INTERNATIONAL RESEARCH AND EVALUATION R. DANFORD

INTERNATIONAL SALT COMPANY JOHN VOIGT

IRAD-GAGE R. BOYD MONTGOMERY

ISTITUTO SPERIMENTALE MODELLI E STRUTTURE

S.P.A.-ITALY FERRUCCIO GERA

IT CORP

MORRIS BALDERMAN

PETER C. KELSALL

LIBRARY

CARL E. SCHUBERT

ITASCA CONSULTING GROUP INC CHARLES FAIRHURST ROGER HART

I.F.T. AGAPITO \& ASSOCIATES INC MICHAEL P. HARDY

J.L. MAGRUDER \& ASSOCIATES I. L. MAGRUDER

JACOBY \& COMPANY CHARLES H. JACOBY

JAMES MADISON UNIVERSITY STEPHEN B. HARPER

JAY L. SMITH COMPANY INC IAY L. SMITH

JOHNS HOPKINS UNIVERSITY JARED L. COHON

KALAMAZOO COLLEGE RALPH M. DEAL

KANSAS DEPT OF HEALTH AND ENVIRONMENT GERALD W. ALLEN

KANSAS STATE GEOLOGICAL SURVEY WILLIAM W. HAMBLETON

KELLER WREATH ASSOCIATES FRANK WREATH

KETTERING FOUNDATION ESTUS SMITH

KIERSCH ASSOCIATES GEOSCIENCES/RESOURCES

CONSULTANTS INC GEORCE A. KIERSCH, PH.D.

KIHN ASSOCIATES HARRY KIHN

KLM ENGINEERING INC B. GEORGE KNIAZEWYCZ

KUTA RADIO

KUTV-TV ROBERT LOY

LACHEL HANSEN \& ASSOCIATES INC DOUGLAS E. HANSEN

LAKE SUPERIOR REGION RADIOACTIVE WASTE PROJECT C. DIXON

LAWRENCE BERKELEY LABORATORY JOHN A. APPS EUGENE P. BINNALL NORMAN M. EDELSTEIN E. MAJER CHIN FU TSANC 1. WANG

LAWRENCE LIVERMORE NATIONAL

LABORATORY

EDNA M. DIDWELL

HUGH HEARO

FRANCOIS E. HEUZE

NAI-HSIEN MAO

LAWRENCE MCKAGUE

THOMAS E. MCKONE

ABELARDO RAMIREZ

LAWRENCE D. RAMSPOTT (2)

DAVID B. SLEMMONS

TECHNICAL INFORMATION DEPARTMENT
WASTE PACKAGE TASK LIBRARY

JESSE L. YOW, JR.

LEACUE OPPOSING SITE SELECTION LINDA S. TAYLOR

LEGISLATIVE COMMISSION ON SCIENCE \& TECHNOLOGY

DALE M. VOLKER

LEIGHTON AND ASSOCIATES INC BRUCE R. CLARK

LIBRARY OF MICHIGAN RICHARD J. HATHAWAY

LOCKHEED ENGINEERING \& MANAGEMENT COMPANY STEVE NACHT

LOS ALAMOS NATIONAL LABORATORY ERNEST A. BRYANT

B. CROWE

AREND MEIJER

C. W. MYERS DONALD T. OAKLEY

LOUISIANA GEOLOGICAL SURVEY RENWICK P. DEVILLE IAMES J. FRILOUX SYED HAQUE

LOUISIANA STATE UNIVERSITY JEFFREY S. HANOR

LOUISIANA TECHNICAL UNIVERSITY LIBRARY R. H. THOMPSON

LYLE FRANCIS MINING COMPANY LYLE FRANCIS

M.J. OCONNOR \& ASSOCIATES LTD M. J. OCONNOR

MARTIN MARIETTA CATHY S. FORE

MARYLAND DEPT OF HEALTH \& MENTAL HYGIENE MAX EISENBERG

MASSACHUSETTS INSTITUTE OF TECHNOLOGY DANIEL METLAY

MCDERMOTT INTERNATIONAL KAREN L. FURLOW

MELLEN GEOLOGICAL ASSOCIATES INC FREDERIC F. MELLEN

MEMBERS OF THE GENERAL PUBLIC ROGER H. BROOKS LAWRENCE CHASE, PH.D. TOM \& SUSAN CLAWSON VICTOR J. COHEN ROBERT DEADMAN GHISLAIN DEMARSILY GERALD A. DRAKE, M.D. ROBERT EINZIGER WARREN EISTER DUNCAN FOLEY

CARL A. GIESE KENNETH GUSCOTT MICHAEL T. HARRIS MICHAEL R. HELFERT JOSEPH M. HENNIGAN CHARLES B. HUNT HAROLD L. JAMES KENNETH S. JOHNSON THOMAS H. LANGEVIN LINDA LEHMAN GEORGE LOUDDER CLIVE MACKAY DUANE MATLOCK W. D. MCDOUGALD MAX MCDOWELL A. ALAN MOGHISSI TONY MORGAN CAROLINE PETTI 
PETER J. SABATINI, JR.

ZUBAIR SALEEM

OWEN SEVERANCE

LEWIS K. SHUMWAY

HARRY W. SMEDES

LEE STOKES

M. J. SZULINSKI

EBIMO D. UMBU

SUSAN D. WILTSHIRE

MERRIMAN AND BARBER CONSULTING

ENGINEERS INC

GENE R. BARBER

MICHIGAN DEPT OF PUBLIC HEALTH ARTHUR W. BLOOMER

MICHIGAN DISTRICT HEALTH DEPT NO. 4 EDGAR KREFT

MICHIGAN ENVIRONMENTAL COUNCIL ROOM 305

MICHICAN GEOLOGICAL SURVEY ROBERT C. REED

MICHIGAN UNITED CONSERVATION CLUBS WAYNE SCHMIDT

MIDDLETON LIBRARY M. S. BOLNER

MINDEN NUCLEAR WASTE INFORMATION

OFFICE

SHIRLEY JOHNSON

MINNESOTA GEOLOGICAL SURVEY MATT S. WALTON

MISSISSIPPI BUREAU OF GEOLOGY MICHAEL B. E. BOGRAD

MISSISSIPPI DEPT OF ENERGY AND

TRANSPORTATION DON CHRISTY

MISSISSIPPI DEPT OF NATURAL RESOURCES ALVIN R. BICKER, JR. CHARLES L. BLALOCK

MISSISSIPPI MINERAL RESOURCES INSTITUTE

MISSISSIPPI STATE DEPT OF HEALTH EDDIE S. FUENTE

MISSISSIPPI STATE UNIVERSITY JOHN E. MYLROIE

MITRE CORP

IESTER A. ETTLINGER

MONTICELLO NUCLEAR WASTE INFORMATION OFFICE

CARL EISEMANN (2)

MORRISON-KNUDSEN COMPANY INC BILL GALE MICHELLE L. PAURLEY

NATIONAL ACADEMY OF SCIENCES JOHN T. HOLLOWAY

NATIONAL BOARD FOR SPENT NUCLEAR FUEL, KARNBRANSLENAMDEN-SWEDEN NILS RYDELL

NATIONAL GROUND WATER INFORMATION CENTER JANET BIX

NATIONAL PARK SERVICE CECIL. D. LEWIS, JR. L. L. MINTZMEYER PETER L. PARRY

NATIONAL PARKS \& CONSERVATION ASSOCIATION TERRI MARTIN

NATIONAL SCIENCE FOUNDATION ROYAL E. ROSTENBACH

NATIONAL WATER WELL ASSOCIATION VALERIE ORR

NEW HAMPSHIRE HOUSE OF REPRESENTATIVES M. ARNOLD WIGHT, JR.

NEW MEXICO BUREAU OF GEOLOGY BILL HATCHELL
NEW MEXICO ENVIRONMENTAL EVALUATION GROUP

ROBERT H. NEILL

NEW MEXICO INSTITUTE OF MINING AND TECHNOLOGY JOHN L. WILSON

NEW YORK ENERGY RESEARCH \&

DEVELOPMENT AUTHORITY JOHN P. SPATH (8)

NEW YORK STATE ASSEMBLY WILLIAM B. HOYT

NEW YORK STATE DEPT OF ENVIRONMENTAL CONSERVATION PAUL MERCES

NEW YORK STATE GEOLOGICAL SURVEY JAMES R. ALBANESE ROBERT H. FICKIES

NEW YORK STATE HEALTH DEPT JOHN MATUSZEK

NEW YORK STATE PUBLIC SERVICE COMMISSION FRED HAAC

NEYER, TISEO, \& HINDO LTD KAL R. HINDO

NORTH CAROLINA STATE UNIVERSITY M. KIMBERLEY

NORTH DAKOTA GEOLOGICAL SURVEY DON L. HALVORSON

NORTHEAST LOUISIANA UNIVERSITY ROBERT E. DOOLEY

NORTHWESTERN UNIVERSITY BERNARD I. WOOD

NUCLEAR SAFETY RESEARCH ASSOCIATION HIDETAKA ISHIKAWA

NUCLEAR WASTE CONSULTANTS ADRIAN BROWN

NUCLEAR WASTE INFORMATION CENTER MISSISSIPPI STATE LAW LIBRARY JUDITH HUTSON

NUS CORP W. C. BELTER

OAK RIDGE NATIONAL LABORATORY

J. O. BLOMEKE

ALLEN G. CROFF

DAVID C. KOCHER

T. F. LOMENICK

FRANCOIS G. PIN

ELLEN D. SMITH

SUSAN K. WHATLEY

OHIO DEPT OF HEALTH ROBERT M. QUILLIN

ONR DETACHMENT DAVID EPP

ONTARIO DEPT OF CIVIL ENGINEERING F. SYKES

ONTARIO HYDRO-CANADA

K. A. CORNELL C. F. LEE

ORANGE COUNTY COMMUNITY COLLEGE LAWRENCE E. OBRIEN

ORGANIZATION FOR ECONOMIC

COOPERATION AND DEVELOPMENT-FRANCE STEFAN G. CARLYLE

PACIFIC NORTHWEST LABORATORY

DON J. BRADLEY

CHARLES R. COLE

WILLIAM CONBERE

PAUL A. EDDY

FLOYD N. HODGES

CHARLES T. KINCAID

I. M. RUSIN

R. JEFF SERNE

STEVEN C. SNEIDER

R. E. WESTERMAN
PARSONS BRINCKERHOFF QUADE \& DOUGLAS INC

T. R. KUESEL

ROBERT PRIETO

PARSONS BRINCKERHOFF/PB-KBB KAROLYN KENNEDY

PARSONS-REDPATH

KRISHNA SHRIYASTAVA

CLEN A. STAFFORD

PQ-KBB INC

JUDITH G. HACKNEY

PENNSYIVANIA STATE UNIVERSITY

MICHAEL GRUTZECK

DELLA M. ROY

WILLIAM B. WHITE

PHYSIKALISCH-TECHNISCHE BUNDESANSTALTW. GERMANY

PETER BRENNECKE

POTASH CORPORATION OF SASKATCHEWAN CANADA

GRAEME G. STRATHDEE

POTASH CORPORATION OF SASKATCHEWAN

MINING LIMITED

PARVIZ MOTTAHED

POWER REACTOR AND NUCLEAR FUEL

DEVELOPMENT CORP-JAPAN

PRESEARCH INC

MARTIN S. MARKOWICZ

R.J. SHLEMON AND ASSOCIATES INC R. J. SHLEMON

RADIAN CORP RICHARD STRICKERT

RANDALL COUNTY LIBRARY

REISPEC INC

GARY D. CALLAHAN

PAUL F. GNIRK

RENSSELAER POLYTECHNIC INSTITUTE BRIAN BAYLY

RHODE ISLAND OFFICE OF STATE PLANNING BRUCE VILD

RICHTON NUCLEAR WASTE INFORMATION OFFICE BOB FREEMAN

RISO NATIONAL LABORATORY-DENMARK LARS CARLSEN

ROCKWELL HANFORD OPERATIONS RONALD C. ARNETT KUNSOO KIM

ROCKWELL INTERNATIONAL ENERGY SYSTEMS GROUP HARRY PEARLMAN

ROGERS \& ASSOCIATES ENGINEERING CORP ARTHUR A. SUTHERLAND ROBERT E. WILEMS

ROY F. WESTON INC MICHAEL CONROY DAVID F. FENSTER VIC MONTENYOHL SAM PANNO JILL RUSPI KAREN ST. JOHN LAWRENCE A. WHITE

ROYAL INSTITUTE OF TECHNOLOCY-SWEDEN IVARS NERETNIEKS ROGER THUNVIK

ROYCES ELECTRONICS INC ROYCE HENNINGSON

SALT LAKE CITY TRIBUNE JIM WOOLF

SAN JOSE STATE UNIVERSITY SCHOOL OF ENGINEERING

R. N. ANDERSON 
SAN JUAN RECORD JOYCE MARTIN

SANDIA NATIONAL LABORATORIES

JOY BEMESDERFER

ROBERT M. CRANWELL

ROBERT GUZOWSKI

THOMAS O. HUNTER

A. R. LAPPIN

R. W. LYNCH

JAMES T. NEAL

E. J. NOWAK

SCOTT SINNOCK

WOLFGANG WAWERSIK

WENDELL WEART

SARGENT \& LUNDY ENGINEERS LAWRENCE L. HOLISH

SAVANNAH RIVER LABORATORY CAROL JANTZEN

SCIENCE APPLICATION KRISHAN K. WAHI

SCIENCE APPLICATIONS INTERNATIONAL CORP MARY LOU BROWN CONNIE COLLIER

BARRY DIAL

ROBERT R. JACKSON

DAVID H. LESTER

JOHN E. MOSIER

ANTHONY MULLER

DOUGLAS A. OUTLAW

HOWARD PRATT

MICHAEL E. SPAETH

ROBERT T. STULA

M. D. VOEGELE

SENECA COUNTY DEPT OF PLANNING \& DEVELOPMENT

SHAFER EXPLORATION COMPANY WILLIAM E. SHAFER

SHANNON \& WILSON INC HARVEY W. PARKER

SIERRA CLUB MARVIN RESNIKOFF

SIERRA CLUB-COLORADO OPEN SPACE

COUNCII. ROY YOUNG

SIERRA CLUB LEGAL DEFENSE FUND H. ANTHONY RUCKEL

SIMECSOL CONSULTING ENGINEERS-FRANCE MATTHEW LEONARD

SOGO TECHNOLOGY INC TIO C. CHEN

SOKAOGON CHIPPEWA COMMUNITY ARLYN ACKLEY

SOUTH DAKOTA GEOLOGICAL SURVEY MERLIN J. TIPTON

SOUTH DAKOTA OFFICE OF ENERGY POUCY STEVEN M. WEGMAN

SOUTHERN CALIFORNIA EDISON CO JOHN LADESICH

SOUTHWEST RESEARCH AND INFORMATION CENTER DON HANCOCK

SPRING CREEK RANCH DALTON RED BRANGUS

SPRINGVILLE CITY LIBRARY

SRI INTERNATIONAL (PS 285) DIGBY MACDONALD

ST \& E TECHNICAL SERVICES INC STANLEY M. KLAINER

STANFORD UNIVERSITY KONRAD B. KRAUSKOPF GEORGE A. PARKS IRWIN REMSON

STATE PLANNING AGENCY BILL CLAUSEN
STATE UNIVERSITY OF NEW YORK AT CORTLAND

JAMES E. BUGH

STATE UNIVERSITY OF NEW YORK AT STONY BROOK

$$
\text { S. REAVEN }
$$

STONE \& WEBSTER ENGINEERING CORP

ARLENE C. PORT

EVERETT M. WASHER

STUDIO GEOLOGICO FOMAR-ITALY

A. MARTORANA

SWEDISH GEOLOGICAL LEIF CARLSSON

SWISHER COUNTY LIBRARY

SYRACUSE UNIVERSITY WALTER MEYER J. E. ROBINSON

SYSTEMS SCIENCE AND SOFTWARE PETER LAGUS

TECHNICAL INFORMATION PROJECT DONALD PAY

TERRAFORM ENGINEERS INC FRANCIS S. KENDORSKI

TEXAS A \& M UNIVERSITY JOHN HANDIN JAMES E. RUSSELL

TEXAS BUREAU OF ECONOMIC GEOIOGY WILLIAM L. FISHER

TEXAS DEPT OF HEALTH DAVID K. LACKER

TEXAS DEPT OF WATER RESOURCES T. KNOWLES

TEXAS GOVERNORS OFFICE STEVE FRISHMAN

TEXAS STATE HOUSE OF REPRESENTATIVES JULIE CARUTHERS

TEXAS TECHNICAL UNIVERSITY C. C. REEVES, JR.

TEXAS WORLD OPERATIONS INC DAVID JEFFERY

THE ANALYTIC SCIENCES CORP JOHN W. BARTLETT

THE BENHAM GROUP KEN SENOUR

THE DAILY SENTINEL JIM SULLIVAN

THE EARTH TECHNOLOGY CORP DANIEL D. BUSH FRED A. DONATH (2) JOSEPH G. GIBSON DAN MELCHIOR JAMES R. MILLER FIA VITAR MATI WERNER KENNETH L. WILSON

THE RADIOACTIVE EXCHANGE EDWARD L. HELMINSKI

THE SEATTLE TIMES ELOUISE SCHUMACHER

THOMSEN ASSOCIATES C. T. GAYNOR, "I

TIMES-PICAYUNE MARK SCHLEIFSTEIN

TIOGA COUNTY PLANNING BOARD THOMAS A. COOKINGHAM

TULIA NUCLEAR WASTE INFORMATION OFFICE NADINE COX

U.S. ARMY CORPS OF ENGINEERS DON BANKS ALAN BUCK

U.S. BUREAU OF LAND MANAGEMENT GREGORY F. THAYN

U.S. BUREAU OF MINES ANTHONY IANNACCHIONE
U.S. BUREAU OF RECLAMATION REGE LEACH

UC-150 \& UC-760

U.S. DEPT OF COMMERCE

PETER A. RONA

U.S. DEPT OF ENERGY

RICHARD BLANEY

REBECCA BOYD

CHED BRADIEY

R. COOPERSTEIN

NEAL DUNCAN

JIM FIORE

LAWRENCE H. HARMON

MICHAELENE PENDLETON (2)

PUBLIC READING ROOM

JANIE SHAHEEN

U.S. DEPT OF ENERCY - CHICAGO OPERATIONS

OFFICE

BARRETT R. FRITZ

PUBLIC READING ROOM

R. SELBY

U.S. DEPT OF ENERGY-ENGINEERING AND

LICENSING DIVISION

RALPH STEIN

U.S. DEPT OF ENERGY-IDAHO OPERATIONS

OFFICE

JAMES F. LEONARD

PUBLIC READING ROOM

U.S. DEPT OF ENERGY - OAK RIDGE

OPERATIONS OFFICE PUBLIC READING ROOM

U.S. DEPT OF ENERGY-OFFICE OF ENERGY RESEARCH

FRANK J. WOBBER

U.S. DEPT OF ENERGY-OSTI (317)

U.S. DEPT OF ENERGY-RICHLAND OPERATIONS

OFFICE

D. H. DAHLEM

U.S. DEPT OF ENERGY-SALT REPOSITORY PROJECT OFFICE

J. O. NEFF

U.S. DEPT OF ENERGY - SAN FRANCISCO

OPERATIONS OFFICE PUBLIC READING ROOM

U.S. DEPT OF ENERGY-WIPP ARLEN HUNT

U.S. DEPT OF LABOR KEIVIN K. WU

U.S. DEPT OF THE INTERIOR

F. L. DOYLE

PAUL A. HSIEH

U.S. ENVIRONMENTAL PROTECTION AGENCY JAMES NEIHEISEL

U.S. ENVIRONMENTAL PROTECTION AGENCYDENVER REGION VIII PHIL NYBERG

U.S. GEOLOGICAL SURVEY GEORGE A. DINWIDDIE VIRGINIA M. GLANZMAN DARWIN KNOCHENMUS

GERHARD W. LEO

EDWIN ROEDDER RAYMOND D. WATTS

U.S. GEOLOGICAL SURVEY-DENVER

M. S. BEDINGER

JESS $M$. CLEVELAND

ROBERT J. HITE

FREDERICK L. PAILLET WILLIAM WILSON

U.S. GEOLOGICAL SURVEY-JACKSON GARALD G. PARKER, JR.

U.S. GEOLOGICAL SURVEY-MENLO PARK MICHAEL CLYNNE 
U.S. GEOLOGICAL SURVEY-RESTON

I-MING CHOU

NEIL PLUMMER

EUGENE H. ROSEBOOM, JR.

DAVID B. STEWART

NEWELL J. TRASK, JR.

U.S. NUCLEAR REGULATORY COMMISSION

R. BOYLE

EILEEN CHEN

DOCKET CONTROL CENTER

GEOSCIENCES BRANCH

PAUL F. GOLDBERG

BANAD N. JAGANNATH

CLYDE JUPITER

PHILIP S. JUSTUS

WALTON R. KELLY

WILLIAM D. LILLEY

JOHN C. MCKINLEY

NRC LIBRARY

EDWARD OCONNELL

JEROME R. PEARRING

JACOB PHILIP

FREDERICK W. ROSS

R. JOHN STARMER

NAIEM S. TANIOUS

JOHN TRAPP

TILAK R. VERMA

MICHAEL WEBER

U.S. SENATE

CARL LEVIN

BILL SARPALIUS

UNION OF CONCERNED SCIENTISTS MICHAEL FADEN

UNITED KINGDOM ATOMIC ENERGY AUTHORITY

A. B. LIDIARD

UNIVERSITE DU QUEBEC EN

ABITIBH-TEMISCAMINGUE AUBERTIN MICHEL

UNIVERSITY COLLGE LONDON B. K. ATKINSON

UNIVERSTY OF ALBERTA-CANADA

F. W. SCHWARTZ

UNIVERSITY OF ARIZONA

JAAK DAEMEN

STANLEY N. DAVIS

I. W. FARMER

KITTITEP FUENKAJORN

JAMES G. MCCRAY

UNIVERSITY OF BRITISH COLUMBIA - CANADA

R. ALLAN FREEZE

UNIVERSITY OF CALIFORNIA AT RIVERSIDE LFWIS COHEN

UNIVERSITY OF CONNECTICUT GARY ROBBINS

UNIYERSTY OF DAYTON RESEARCH LAB NACHHATTER S. BRAR

UNIVERSITY OF MUNOIS AT

URBANA-CHAMPAIGN

ALBERT I. MACHIELS

UNIVERSTY OF LOWELI

JAMES R. SHEFF
UNIVERSITY OF MARYLAND

AMERICAN NUCLEAR SOCIETY

LUKE L. Y. CHUANC

UNIVERSITY OF MASSACHUSETTS GEORGE MCGILL

UNIVERSITY OF MISSOURI AT COLUMBIA W. D. KELLER

UNIVERSITY OF MISSOURI AT KANSAS CITY EDWIN D. GOEBEL

SYED E. HASAN

UNIVERSITY OF MISSOURI AT ROLLA ALLEN W. HATHEWAY

UNIVERSITY OF NEVADA AT RENO BECKY WEIMER-MCMILLION

UNIVERSITY OF NEW MEXICO DOUGLAS G. BROOKINS RODNEY C. EWING

UNIVERSITY OF ROCHESTER DAVID ELMORE

UNIVERSITY OF SOUTHERN MISSISSIPPI CHARLES R. BRENT DANIEL A. SUNDEEN

UNIVERSTTY OF TEXAS AT AUSTIN BUREAU OF ECONOMIC GEOLOGY CAROLYN E. CONDON PRISCILLA P. NELSON JOHN M. SHARP, JR THE GENERAL LIBRARIES

UNIVERSITY OF TEXAS AT SAN ANTONIO DONALD R. LEWIS

UNIVERSITY OF TOLEDO DON STIERMAN

UNIVERSITY OF UTAH THURE CERLING STEVEN I. MANNING MARRIOTT LIBRARY JAMES A. PROCARIONE GARY M. SANDQUIST

UNIVERSITY OF UTAH RESEARCH INSTITUTE LIBRARY HOWARD P. ROSS

UNIVERSTTY OF WASHINGTON DAVID BODANSKY M. A. ROBKIN

UNIVERSITY OF WATERIOO CHRIS FORDHAM

UNIVERSITY OF WISCONSIN-MADISON B. C. HAIMSON

UNIVERSITY OF WISCONSIN-MILWAUKEE HOWARD PINCUS

UNIVERSITY OF WISCONSIN CENTER JANESVILE

UNIVERSITY OF WYOMING PETER HUNTOON

USGS NATIONAL CENTER JIM ROLLO

UTAH DEPT OF HEALTH LARRY F. ANDERSON

UTAH DEPT OF TRANSPORTATION DAVID LLOYD

UTAH DIVISION OF PARKS \& RFCREATION GORDON W. TOPHAM
UTAH GEOLOGICAL AND MINERAL SURVEY MAGE YONETANI

UTAH SOUTHEASTERN DISTRICT HEALTH DEPT ROBERT L. FURLOW

UTAH STATE GEOLOGIC TASK FORCE DAVID D. TILLSON

UTAH STATE UNIVERSITY DEPT OF GEOLOGY 07

V. RAJARAM, P.E. V. RAJARAM

VANDERBILT UNIVERSITY FRANK L. PARKER

VEGA NUCLEAR WASTE INFORMATION OFFICE EFFIE HARLE

VERMONT STATE NUCLEAR ADVISORY PANEL VIRGINIA CALLAN

VIRCINIA DEPT OF HEALTH ROBERT G. WICKLINE

VIRGINIA POWER COMPANY B. H. WAKEMAN

WASHINGTON HOUSE OF REPRESENTATIVES RAY ISAACSON

WASHINGTON STATE DEPT OF ECOLOGY TERRY HUSSEMAN

WATTLAB

BOB E. WATT

WEST VALLFY NUCLEAR SERVICES COMPANY INC

LARRY R. EISENSTATT

WESTERN MICHIGAN UNIVERSITY ROBERT KAUFMAN W. THOMAS STRAW

WESTERN STATE COLLEE FRED R. PECK

WESTINGHOUSE ELECTRIC CORP WIPP PROJECT

WESTINGHOUSE IDAHO NUCLEAR COMPANY INC

NATHAN A. CHIPMAN

WESTON GEOPHYSICAL CORP CHARIFNE SULIIVAN

WEYER CORP INC K. U. WEYER

WILUAMS AND ASSOCIATES INC GERRY WINTER

WISCONSIN DEPT OF NATURAL RESOURCES DUWAYNE F. GEBKEN

WISCONSIN STATE SENATE JOSEPH STROHI

WITHERSPOON, AIKEN AND LANGLEY RICHARD FORREST

WOODWARD-CIYDE CONSUITANTS

RANDAIL. L. LENTELL

ASHOK PATWARDHAN WESTERN REGION LIBRARY

YALE UNIVERSITY G. R. HOLEMAN BRIAN SKINNER

YORK COLLECE OF PENNSYLVANIA JERI LEE JONES 